Alaska Department of Natural Resources

Division of Geological \& Geophysical Surveys

\title{
Preliminary volcano-hazard assessment for Okmok Volcano, Umnak Island, Alaska
}

Report of Investigations 2004-3
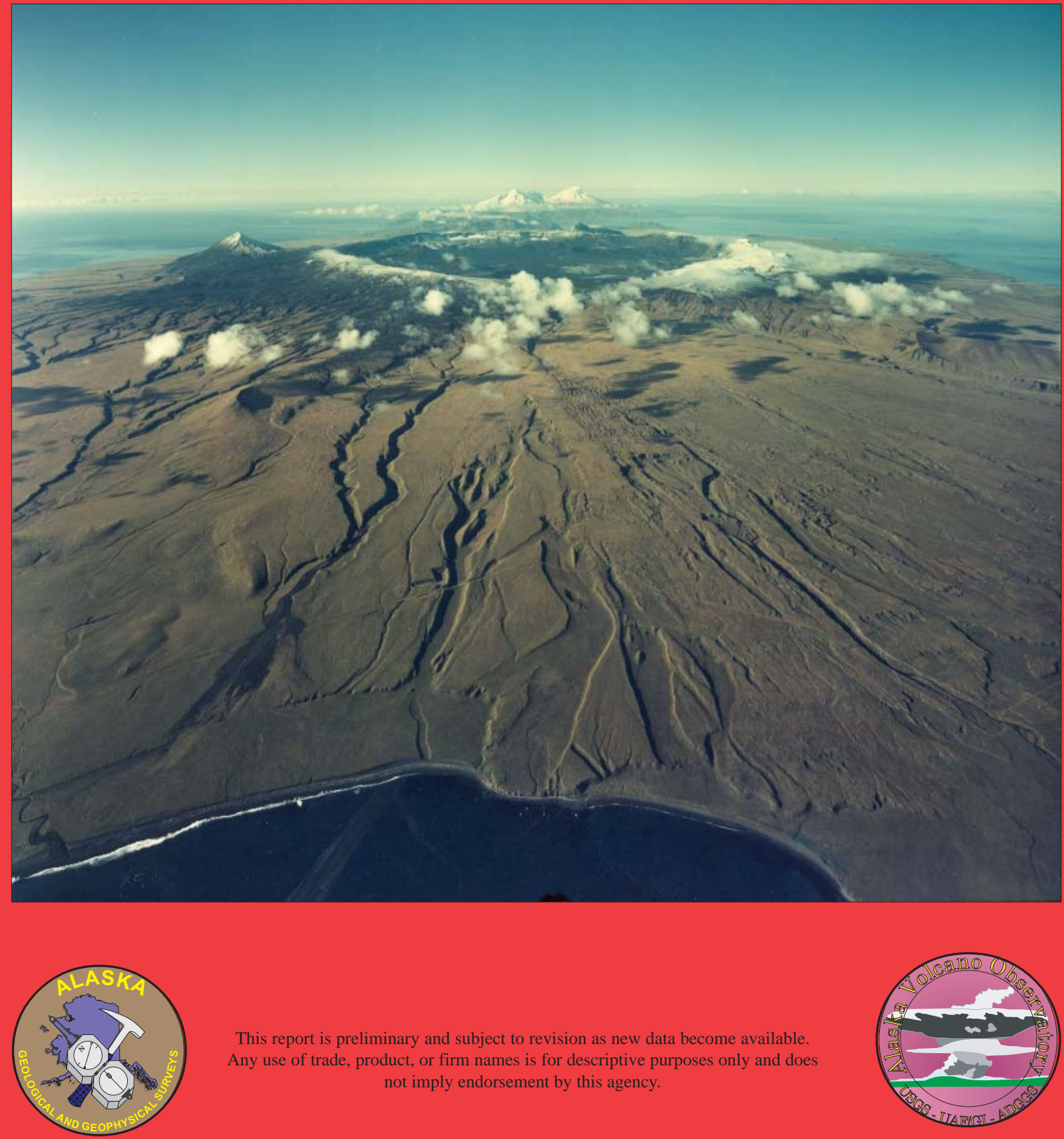

This report is preliminary and subject to revision as new data become available. Any use of trade, product, or firm names is for descriptive purposes only and does not imply endorsement by this agency. 
The Alaska Volcano Observatory (AVO) was established in 1988 to carry out volcano monitoring, eruption notification, and volcanic hazards assessments in Alaska. The cooperating agencies of AVO are the U.S. Geological Survey (USGS), the University of Alaska Fairbanks Geophysical Institute (UAFGI), and the Alaska Division of Geological \& Geophysical Surveys (ADGGS). AVO also plays a key role in notification and tracking of eruptions on the Kamchatka Peninsula of Russia as part of a formal working relationship with the Kamchatkan Volcanic Eruptions Response Team (KVERT).

Cover photo: Oblique aerial view of Okmok Volcano showing the 10-kilometer-wide summit caldera (view to the southwest). The flanks of the volcano display deeply incised channels eroded in 2,000-year-old pyroclastic flow deposits by a catastrophic flood from a lake that formerly occupied the summit caldera. Photo supplied by the Aeromap Corporation, taken on September 27, 1996. 
Alaska Department of Natural Resources
Division of Geological \& Geophysical Surveys

Preliminary Volcano-Hazard Assessment for OkmokVolcano, Umnak Island Alaska

by J.E. Begét ${ }^{1}$, J.F. Larsen², C.A. $\mathrm{Neal}^{3}$, C.J. $\mathrm{Nye}^{4}$, and J.R. Schaefer ${ }^{4}$

Report of Investigations 2004-3

2005

This DGGS Report of Investigations is a final report of scientific research. It has received technical review and may be cited as an agency publication.

${ }^{1}$ Department of Geology and Geophysics, University of Alaska, P.O. Box 755780, Fairbanks, Alaska 99775-5780

${ }^{2}$ Geophysical Institute, University of Alaska, P.O. Box 757320, Fairbanks, Alaska 99775-7320

${ }^{3}$ U.S. Geological Survey, Alaska Volcano Observatory, 4200 University Drive, Anchorage, AK 99508

${ }^{4}$ Alaska Division of Geological \& Geophysical Surveys, 3354 College Rd., Fairbanks, Alaska 99709-3707 


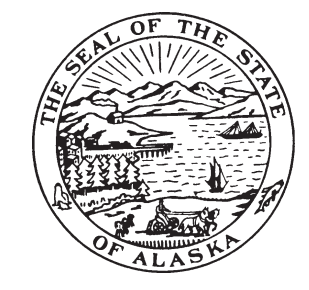

STATE OF ALASKA

Frank Murkowski, Governor

DEPARTMENT OF NATURAL RESOURCES

Tom Irwin, Commissioner

\section{DIVISION OF GEOLOGICAL \& GEOPHYSICAL SURVEYS Mark Myers, Director}

Division of Geological \& Geophysical Surveys publications can be inspected at the following locations. Address mail orders to the Fairbanks office.

\author{
Alaska Division of Geological \\ \& Geophysical Surveys \\ 3354 College Rd. \\ Fairbanks, Alaska 99709-3707 \\ Elmer E. Rasmuson Library \\ University of Alaska Fairbanks \\ Fairbanks, Alaska 99775-1005
}

\author{
Alaska Resource Library \\ and Information Services (ARLIS) \\ 3211 Providence Drive \\ Anchorage, Alaska 99508 \\ University of Alaska Anchorage Library \\ 3211 Providence Dr. \\ Anchorage, Alaska 99508
}

\author{
Alaska State Library \\ State Office Building, 8th Floor \\ 333 Willoughby Avenue \\ Juneau, Alaska 99811-0571
}

This publication released by the Division of Geological \& Geophysical Surveys was produced and printed in Fairbanks, Alaska, by DGGS at a cost of \$17 per copy. Publication is required by Alaska Statute 41, "to determine the potential of Alaskan land for production of metals, minerals, fuels, and geothermal resources; the location and supplies of groundwater and construction materials; the potential geologic hazards to buildings, roads, bridges, and other installations and structures; and shall conduct such other surveys and investigations as will advance knowledge of the geology of Alaska.” 


\section{CONTENTS}

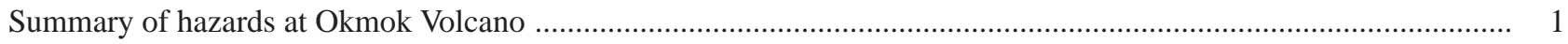

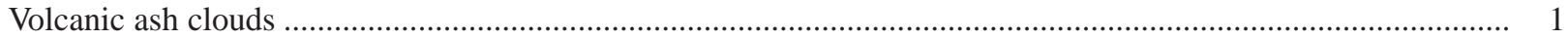

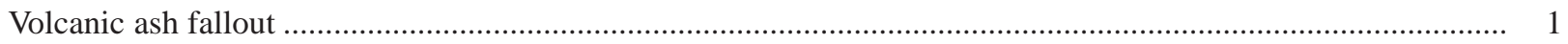

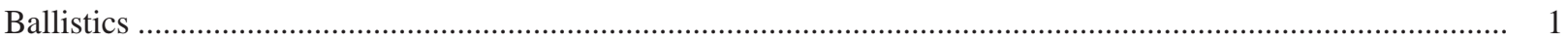

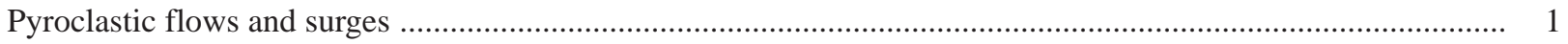

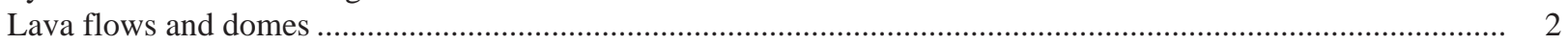

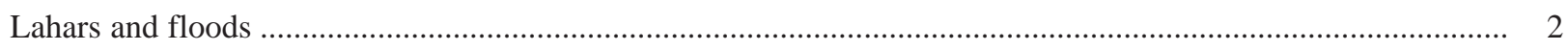

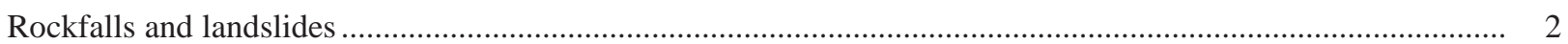

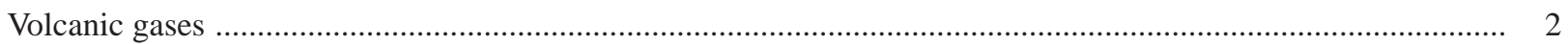

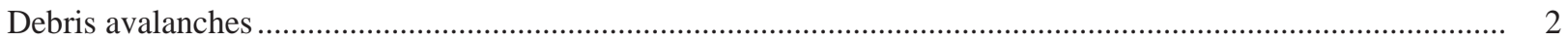

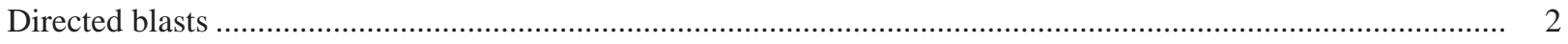

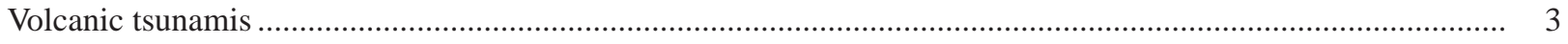

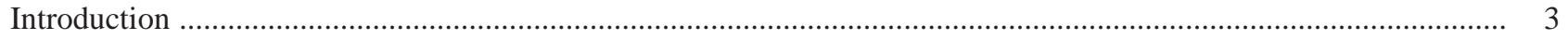

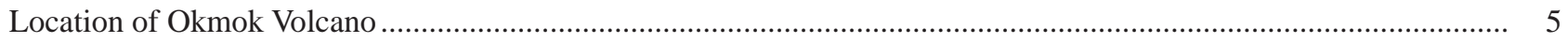

Prehistoric eruptive history of Okmok Volcano ................................................................................................ 6

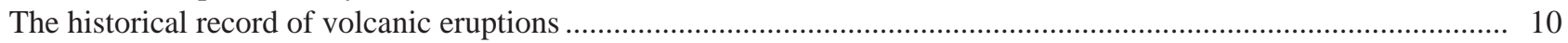

Potentially hazardous volcanic phenomena at Okmok Volcano ................................................................................ 12

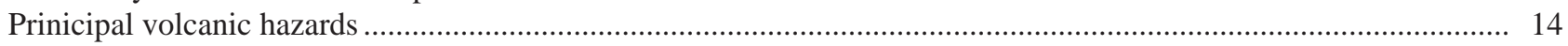

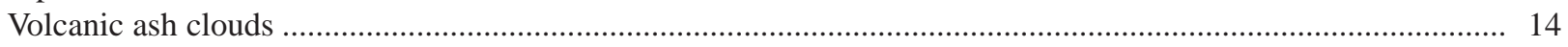

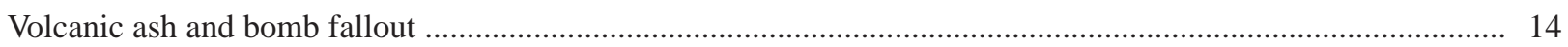

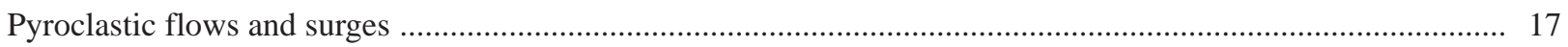

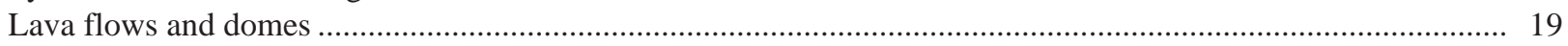

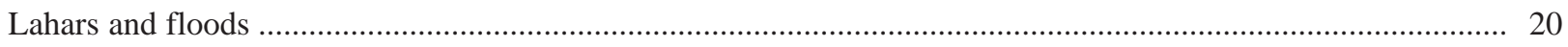

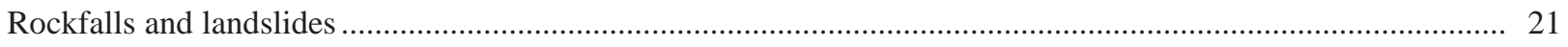

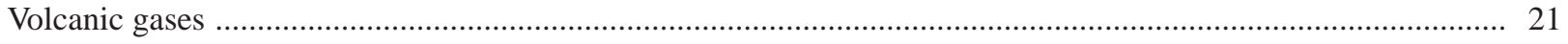

Volcanic hazards likely to be associated only with extremely large eruptions of Okmok Volcano .............................. 22

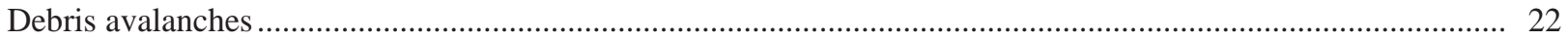

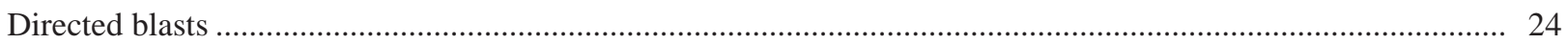

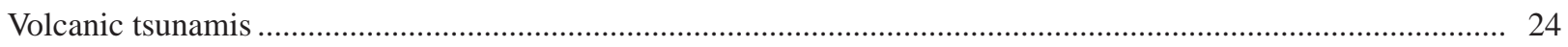

Could another caldera-forming eruption occur at Okmok? .................................................................................... 24

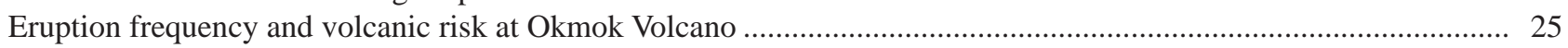

Precursory activity, volcano monitoring, and hazard mitigation ......................................................................... 26

What can be done to prepare for an eruption at Okmok Volcano? ................................................................................ 28

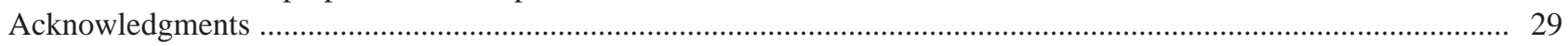

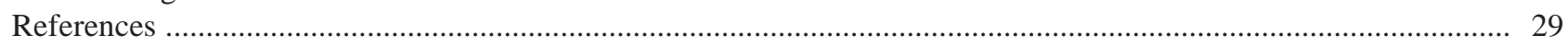

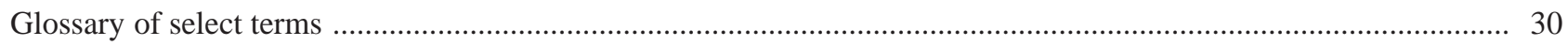

\section{SHEET}

Sheet 1. Preliminary volcano-hazard assessment for Okmok Volcano, Umnak Island, Alaska _ [in envelope]

\section{FIGURES}

Figure 1. Map showing location of Okmok Volcano with respect to other volcanoes in the

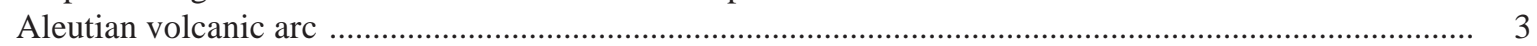

2. Shaded relief map showing Okmok Volcano on eastern Umnak Island ..................................................... 4

3. Photo of Okmok Volcano as seen from the International Space Station May 18, 2001, showing the location of the summit caldera rim, Crater Creek, Tulik Volcano, and the other volcanic cones discussed in the text

4. Illustration showing prehistoric eruption history of Okmok Volcano, based on geologic mapping and stratigraphic studies ........................................................................... 6

5. Simplified sketch showing the development of a caldera ....................................................................... 7

6. Photo showing prehistoric volcanic ash deposits from Okmok Volcano preserved near Kettle Cape, about 10 kilometers south of the caldera rim . 
7. Photo showing the flanks of Okmok Volcano deeply buried by two thick pyroclastic flows produced by two huge caldera-forming eruptions

8. Photo showing steam rising from Cone A, the currently active vent within the caldera at Okmok Volcano ......

9. Sketch of a stratovolcano and simplified illustrations of various volcanic hazards that typically accompany eruptions

10. Illustration showing average wind direction over the southwestern Alaska Peninsula and Cook Inlet

11. Illustration showing selected representative flight paths of commercial freight and passenger airlines crossing the North Pacific

12. Sketch of phenomena that accompany typical explosive eruptions at Okmok Volcano..... 16

13. Illustration showing ash fall and ballistic hazard areas on Umnak Island during explosive eruptions within the caldera at Okmok Volcano.....

14. Illustration showing areas likely to be affected by pyroclastic flows 19

15. Illustration showing areas likely to be affected by floods and lahars

16. Photo showing large amounts of steam and gas emitted from fumaroles on Cone A

17. Illustration showing potential source areas for debris avalanches 23

18. Illustration showing location of seismic and geodetic monitoring stations around Okmok Volcano 27

19. Alaska Volcano Observatory (AVO) level-of-concern color code

\section{TABLE}

Table 1. Historical eruption record of Okmok Volcano 


\title{
PRELIMINARY VOLCANO-HAZARD ASSESSMENT FOR OKMOK VOLCANO, UMNAK ISLAND, ALASKA
}

\author{
by James E. Begét, Jessica F. Larsen, Christina A. Neal, Christopher J. Nye, and Janet R. Schaefer
}

\section{SUMMARY OF HAZARDS AT OKMOK VOLCANO}

Okmok Volcano is an active volcano located on the northeast end of Umnak Island, about 100 kilometers southwest of Dutch Harbor. The volcano is capped by a large, circular caldera, 10 kilometers in diameter and 500 to 800 meters deep, that formed during catastrophic eruptions about 12,000 and 2,000 years ago. Since then, more than a dozen separate vents within the caldera have erupted, some of them multiple times, to produce lava flows and widespread tephra (volcanic ash) deposits, with the most recent eruption occurring in 1997. Very large floods and lahars also have accompanied past eruptions, one of which destroyed an Aleut village in 1817. Multiple eruptions of lava and ash also have occurred from vents on the volcano's flanks. The volcano's long-term pattern of frequent eruptions, and dramatic intra-caldera deformation and accompanying seismicity since 1997 show that it remains active, and almost certainly will be the site of explosive and nonexplosive eruptions in the future. Understanding the variety of potential hazards associated with different types of volcanic processes typical of Okmok Volcano can help minimize the impacts of future eruptions.

\section{Volcanic ash clouds}

The principal hazard associated with future explosive eruptions of Okmok Volcano is the generation of clouds of pulverized rock debris, pumice, volcanic ash, and gas which are blasted high into the atmosphere and then drift away from the volcano with the wind. Ash-rich clouds produced during large eruptions can reach heights of 10 to 20 kilometers or more above the volcano, although most recent eruptions of Okmok have been smaller. Prevailing winds usually will carry ash clouds to the northeast and east of the volcano, but dispersal in any other direction is possible depending on prevailing winds at the time of the eruption. All aircraft should avoid flying near ash clouds, as contact with ash can damage aircraft windows and instruments, clog air vents, and shut down jet engines.

Volcanic ash fallout

Volcanic ash has been erupted repeatedly from Okmok Volcano during the last several hundred to several thousand years. During typical eruptions ash may accumulate to depths of a meter or more near erupting vents within the caldera, and to depths of several centimeters or more in areas lying downwind on the flanks of the volcano. Even small amounts of fine ash fallout may cause respiratory problems in some humans and animals. Re-suspension of ash by winds may prolong the unpleasant effects of ash fallout long after an eruption. Heavy ash fallout may interfere with power generation and electrical equipment, damage air filters and gasoline engines, interrupt radio and cell phone transmissions, and greatly reduce visibility. The weight of very thick ash falls may collapse roofs, especially when mixed with rain or snow. Ash deposits from the largest prehistoric, caldera-forming eruption of Okmok Volcano are up to 10 centimeters thick near the city of Unalaska, 100 kilometers to the northeast.

\section{Ballistics}

Explosive eruptions can blast pebble- to boulder-sized fragments of rock, ice, or pumice into the air, where they travel on arcuate, ballistic trajectories away from the vent. These projectiles, called ballistics, fall at high speed, and can injure or kill people, and crush or damage equipment and buildings. Most ballistics will fall within a few kilometers of the vent.

\section{Pyroclastic flows and surges}

Eruptions from different vents within the summit caldera at Okmok Volcano have produced pyroclastic flows and surges on numerous occasions during the last 2,000 years. Pyroclastic flows (incandescent flows of ash, gas, and coarse volcanic debris) and surges (hurricane-force blasts of turbulent hot gas and ash clouds) can race down slopes at speeds as great as 100 meters per second, travel 10 to 30 kilometers from the vent, and overtop hills and other topographic obstacles. Future eruptions of pyroclastic flows and surges from vents within the caldera at Okmok Volcano would pose a significant hazard to any people or equipment within about 10 kilometers of the caldera. More rarely, unusually large eruptions might affect the flanks of Okmok and reach coastal areas around the volcano. The

\section{THE ALASKA VOLCANO HAZARD ASSESSMENT SERIES}

This report is part of a series of volcano hazard assessments being prepared by the Alaska Volcano Observatory. The reports are intended to describe the nature of volcanic hazards at Alaska volcanoes and show the extent of hazardous areas with maps, photographs, and other appropriate illustrations. The reports are preliminary and subject to revision as new data become available. 
Crater Creek drainage, where the caldera wall has been breached, is especially vulnerable to the effects of pyroclastic flows and surges.

\section{Lava flows and domes}

Flows of molten rock (lava) may erupt in the future from vents in the summit caldera or from flank vents around Okmok Volcano. These flows will probably move slowly, at rates of only a few meters to tens of meters per hour, and pose little hazard to humans. Lava flows may develop steep, blocky fronts, and avalanching of blocks from a flow front could be hazardous to someone nearby. Lava flows from vents within the caldera, like those that have occurred repeatedly during the last century, are unlikely to reach the flanks of the volcano.

\section{Lahars and floods}

The rapid release of water from lakes within the caldera at Okmok Volcano may produce large floods of water and volcanic debris. An eruption in 1817 produced a flood down Crater Creek that destroyed an Aleut village near Cape Tanak. Hot volcanic debris erupted onto the flanks of the volcano may also melt snow, forming floods or fast-moving slurries of water, mud, rocks, and sand, called lahars. Lahars may also occur when thick deposits of proximal ash are rapidly eroded by heavy rainfall following eruptions. Lahars and floods are most likely to affect the Crater Creek area, but may affect any area on the upper slopes of the volcano or areas near streams and valleys on the lower flanks.

\section{Rockfalls and landslides}

The steep cliffs that form the caldera walls, bedrock cliffs, volcanic cones, and steep lava flow fronts are prone to rockfalls and small landslides. The frequency and size of such events is likely to increase during future eruptions and earthquakes.

\section{Volcanic gases}

Volcanic vents often emit steam and gases, including hydrogen sulfide and carbon dioxide, in concentrations that are potentially harmful to humans. In 2002, several groups of fumaroles in the caldera of Okmok Volcano were active, with especially vigorous steam and gas emissions occurring from vents at Cone A. Lava flows and pyroclastic flows also emit large amounts of steam and gas, and steam continues to be produced from the lava flow erupted from Cone A in 1997. Dangerous invisible, odorless volcanic gases can collect in low-lying areas near fumaroles, making it inadvisable to descend into craters, caves, or fissures occupied by fumaroles.

\section{Some varieties of hazardous phenomena occur very rarely, but might possibly accompany extremely large future eruptions of Okmok Volcano. These include: \\ Debris avalanches}

Debris avalanches are rapidly moving masses of rock debris produced by large-scale landslides and rockfalls that travel many kilometers from their source, burying everything in their path. They can be triggered by eruptions, volcanic earthquakes, or regional earthquakes, or they may occur without an obvious cause. Within the last 2,000 years a prehistoric debris avalanche originated on Tulik Volcano (an old volcanic peak, on the south side of Okmok Volcano) and traveled more than 6 kilometers south to the sea. The hazard from debris avalanches is limited to areas around Tulik Volcano, Jag Peak, and other high cones on the flanks of Okmok Volcano, as well as areas within the caldera. Debris avalanches and large rockfalls may also occur from large, growing, lava domes.

\section{Directed blasts}

A directed blast is a laterally directed explosion of the volcano caused by rapid release of internal pressure. Most directed blasts are caused by a slope failure of newly erupted lava domes or sector collapse of the summit edifice into a debris avalanche, resulting in rapid depressurization of a shallow magma body. Directed blasts can destroy structures throughout a large radial zone extending 10 to 25 kilometers away from the source of the blast. There is no evidence of dome eruptions or lateral blasts at Okmok Volcano within the last 2,000 years, but such volcanic phenomena may occur in the future.

\section{SUGGESTIONS FOR READING THIS REPORT}

Readers who want a brief overview of the hazards at Okmok Volcano are encouraged to read the summary and consult sheet 1 and the illustrations. Individual sections of this report provide a slightly more comprehensive overview of the various hazards at Okmok Volcano. A glossary of geologic terms is included and additional information about Okmok Volcano may be obtained by consulting the references cited at the end of this report. 


\section{Volcanic tsunamis}

Debris avalanches or pyroclastic flows that travel into the sea or lakes may generate unusually large waves, also known as volcanic tsunamis, by rapidly displacing water. Tsunamis are also occasionally produced by volcanic earthquakes, explosions, or other eruptive processes. If the lakes within the caldera are affected by future eruptions, it is possible that waves will be generated that will inundate areas around their shorelines and produce floods down Crater Creek. Eruptions large enough to produce volcanic tsunamis in the ocean are much less likely. However, pyroclastic flows produced during the caldera-forming eruptions about 2,000 years ago traveled many kilometers into the sea beyond the flanks of the volcano, and geologic evidence suggests a tsunami was generated at that time. Although an eruption of Okmok Volcano of sufficient magnitude to send large volumes of material into the Pacific Ocean or Bering Sea is highly unlikely to occur in the near future, the recurrence of such an eruptive event and a resultant volcanic tsunami would probably pose a risk to low-lying coastal areas around the shores of Umnak Island, westernmost Unalaska Island, and Bogoslof Island.

\section{INTRODUCTION}

Okmok Volcano is part of the Aleutian volcanic arc, a chain of more than 40 active volcanoes extending more than 2,000 kilometers from the far western end of the Aleutian Islands to the Cook Inlet area of south-central Alaska (fig. 1). The Aleutian arc is one of the most volcanically active regions on earth, with eruptions typically occurring every year at one or more of the volcanoes. During the last several hundred years, Okmok Volcano has been one of the most active of any of the volcanoes in the Aleutian arc, with eruptions occurring every 10 to 20 years (Miller and others, 1998). The most recent eruption occurred in 1997, when Cone A in the caldera at Okmok Volcano was active for months, repeatedly erupting low ash clouds and producing a voluminous lava flow. Geologic evidence from recent scientific studies suggests that this pattern of frequent eruptions of Okmok has gone on for millennia.

Okmok is a shield volcano covering more than 120 square kilometers and topped by an 8- to 10-kilometerdiameter summit caldera that formed during two recent large eruptions (figs. 2 and 3). The summit caldera is partially filled with lava flows, tuff cones, cinder cones, and other volcanic deposits. The caldera rim reaches to 1,000 to 1,150 meters in elevation, and stands 500 to 800 meters above the caldera floor. A single small glacier, covering about 1.5 square kilometers and partly buried in tephra produced by recent eruptions of cones in the caldera, mantles part of the south wall of the caldera, but during the last ice age glaciers covered the volcano's summit and descended on all sides of the volcano's flanks. The caldera walls expose numerous lava flows, pyroclastic flow deposits, and scoria fall

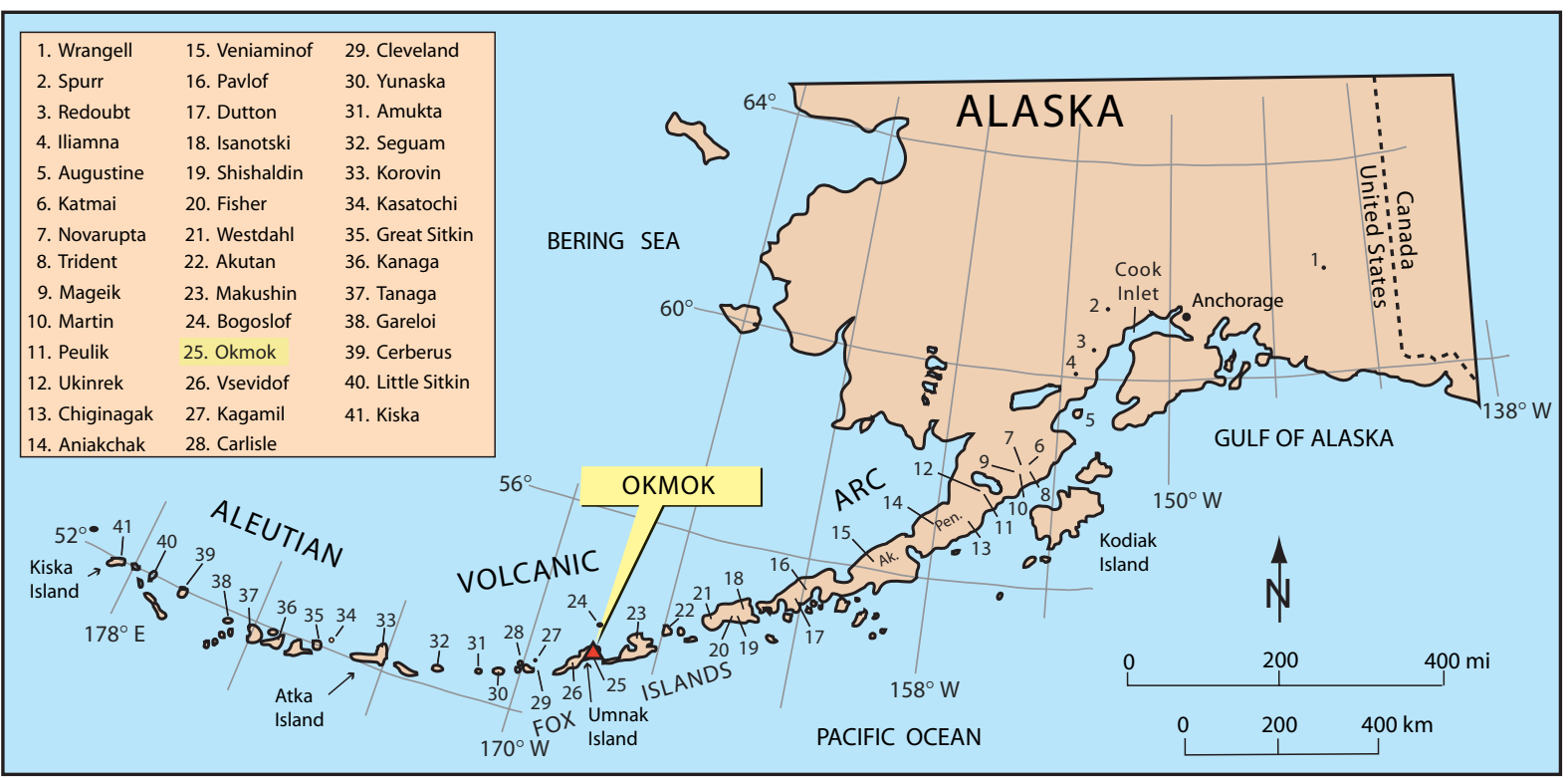

Figure 1. Location of Okmok Volcano with respect to other volcanoes in the Aleutian volcanic arc. All of these volcanoes should be considered active and capable of eruptions in the near future. 
deposits erupted early in the history of Okmok Volcano. Two unnamed lakes, one that formed after a lava flow erupted in 1957-1958, blocking part of the caldera floor, occur within the caldera. Crater Creek originates from the larger and easternmost of the two lakes, and also is fed by large springs. Crater Creek flows out of the caldera through a narrow breach in the caldera walls (fig. 3).

Most of the flanks of Okmok Volcano outside of the central caldera consist of gentle slopes that largely have been buried by pyroclastic flow and volcanic ash deposits, and then incised by streams in steep-sided valleys that originate at the caldera rim. Tulik Volcano, a large flank vent, stands high above the southeast caldera rim, reaching an elevation of 1,253 meters above mean sea level (1,253 meters asl) (fig. 3). Six other large volcanic cones rise 100 to 300 meters above the ash flow surface on the southeast and southwest flanks of the volcano, the tallest of which is named Jag Peak (approximately 850 meters asl). More than 20 small cinder cones and lava flows occur high on the upper north and northeastern flanks of the volcano and around the caldera rim, and at least 10 additional cinder cones, some with extensive coeval lava flows, occur at distances of 10 to15 kilometers from the caldera rim on the southeast, east, north, and northeast flanks of the volcano (Byers, 1959).

This report on the volcanic hazards of Okmok is based on the historical record of eruptions during the past 250 years, combined with geologic evidence of the behavior of the volcano during the last 12,000 years. The past eruptive history of Okmok is the best indicator of likely events and scenarios that may occur during future eruptions. This report discusses the effects of eruptions on those portions of Umnak Island around

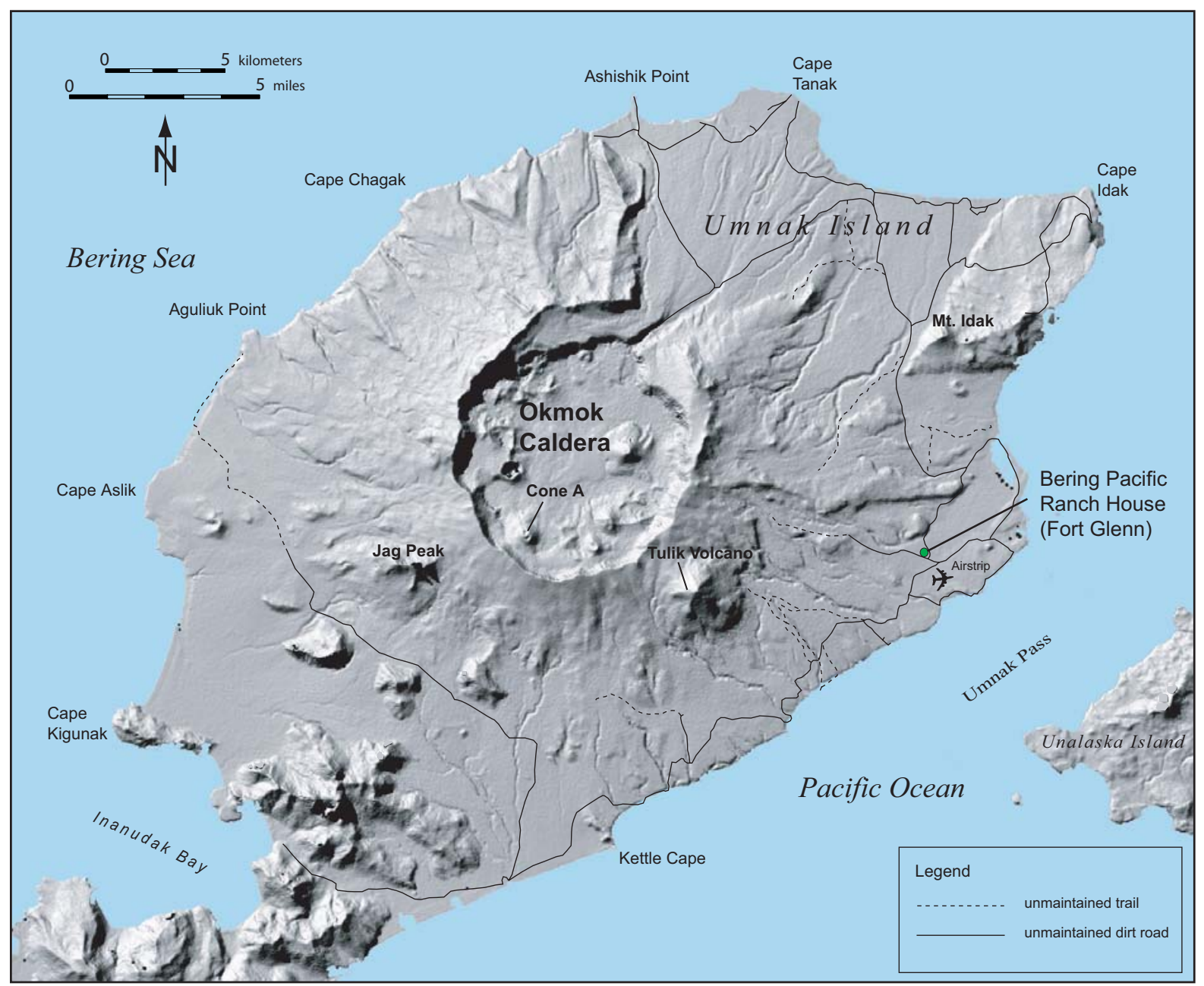

Figure 2. Shaded relief map showing Okmok Volcano on eastern Umnak Island. Also shown are the locations of principal geographic features and the Bering Pacific Ranch, the only permanently occupied site near the volcano. The volcano is dominated by a 10-kilometer-wide summit caldera. 
Okmok as well as on areas at greater distances from the volcano, and constitutes the first comprehensive report on possible impacts of future eruptions of Okmok Volcano. The present status of volcano monitoring efforts and the procedure for eruption notification and dissemination of information are also discussed. This report includes maps and illustrations that indicate potential hazard zones associated with different types of eruptions. A glossary of selected volcanic and geologic terms is included at the end of the report.

\section{LOCATION OF OKMOK VOLCANO}

Okmok Volcano is located on the eastern end of Umnak Island in the eastern Aleutian Islands, about 1,500 kilometers southwest of the city of Anchorage and 100 kilometers west of Unalaska, the largest city in the Aleutian Islands. Okmok Volcano is part of the Aleutian volcanic arc that extends more than 2,000 kilometers across southern Alaska and the Aleutian Islands (fig. 1).

Umnak Island was occupied by thousands of U.S. Army and Army Air Corps troops during World War II, who built numerous roads, airstrips, and buildings centered around Fort Glenn on the easternmost coast of Umnak Island. Fort Glenn was decommissioned and abandoned after World War II, and in 2002 no more than several dozen people at a time work at or visit the Bering Pacific cattle ranch located at the former site of Fort Glenn (fig. 2). There are no other permanent settlements in the vicinity of Okmok Volcano, but most areas around the volcano are regularly visited by the ranch workers. Additional visits by hikers, mountain climbers, geologists, fishermen, hunters, and others occur each year. The only other permanently inhabited site on Umnak Island is the village of Nikolski, with a population of about 50, located at the western end of Umnak Island, about 100 kilometers southwest of Okmok Volcano.

The Bering Sea and the North Pacific Ocean around Okmok are the sites of some of the most productive fisheries in the world, and at almost any time of the year commerical fishing boats pass by and work around Umnak Island. The port of Dutch Harbor and adjacent city of Unalaska, on the eastern end of Unalaska, are home to many of the fishing boats and constitute one of

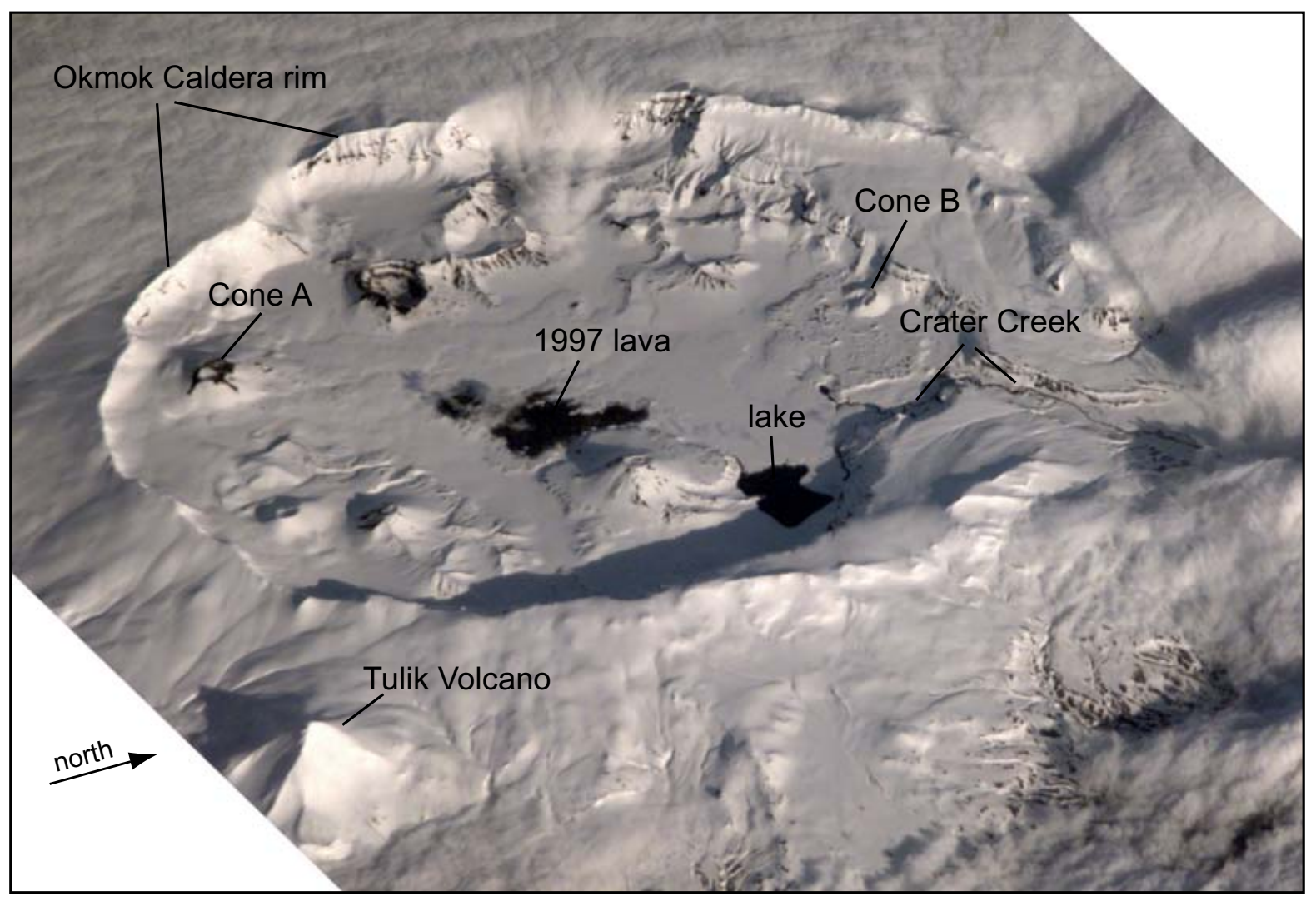

Figure 3. Okmok Volcano as seen from the International Space Station May 18, 2001, showing the location of the summit caldera rim, Crater Creek, Tulik Volcano, and the other volcanic cones discussed in the text. NASA image \#ISS002E6065, courtesy of Earth Sciences and Image Analysis Laboratory, NASA Johnson Space Center. 
the largest commercial fishing ports in America. Dutch Harbor and Unalaska are also the sites of the nearest airport, and are the governmental, commercial, and transportation center for the Aleutian Islands, as well as an important international containerized shipping hub for the North Pacific region.

There is no economic development near Okmok Volcano itself, other than the Bering Pacific cattle ranch. Mineral and geothermal exploration have occurred at Okmok Volcano and around Hot Springs Valley and Geyser Bight, 30 kilometers to the southwest. It is possible that increased tourism, mining, development of geothermal steam resources, or other activities may occur in these areas or at other sites around Okmok Volcano in the future.

Finally, Okmok Volcano lies directly beneath busy air traffic corridors across the North Pacific, and large numbers of both passenger and freight aircraft fly over Okmok Volcano and nearby areas of the North Pacific Ocean daily.

\section{PREHISTORIC ERUPTIVE HISTORY OF OKMOK VOLCANO}

The volcanic deposits of Okmok Volcano were first studied and mapped by geologists in the aftermath of World War II, when volcanic eruptions in the caldera threatened operations at Fort Glenn (Robinson, 1948; Wilcox, 1959, Byers, 1959). The petrology of the volcano was restudied in the early 1980s (Nye, 1983; Nye and Reid, 1985). New geologic studies began at Okmok in 1997 by personnel of the Alaska Volcano Observatory, and a new geologic map of the entire volcano is currently being produced in order to better understand the magnitude and history of past volcanism at Okmok Volcano. Figure 4 illustrates the prehistoric eruption history of Okmok Volcano, based on the most recent geologic mapping and stratigraphic studies.

Because the written record of volcanism at Okmok Volcano goes back only 200 years, geologic and geochronologic studies of prehistoric eruption deposits were conducted in order to estimate the long-term style, magnitude, and frequency of volcanic eruptions. Okmok

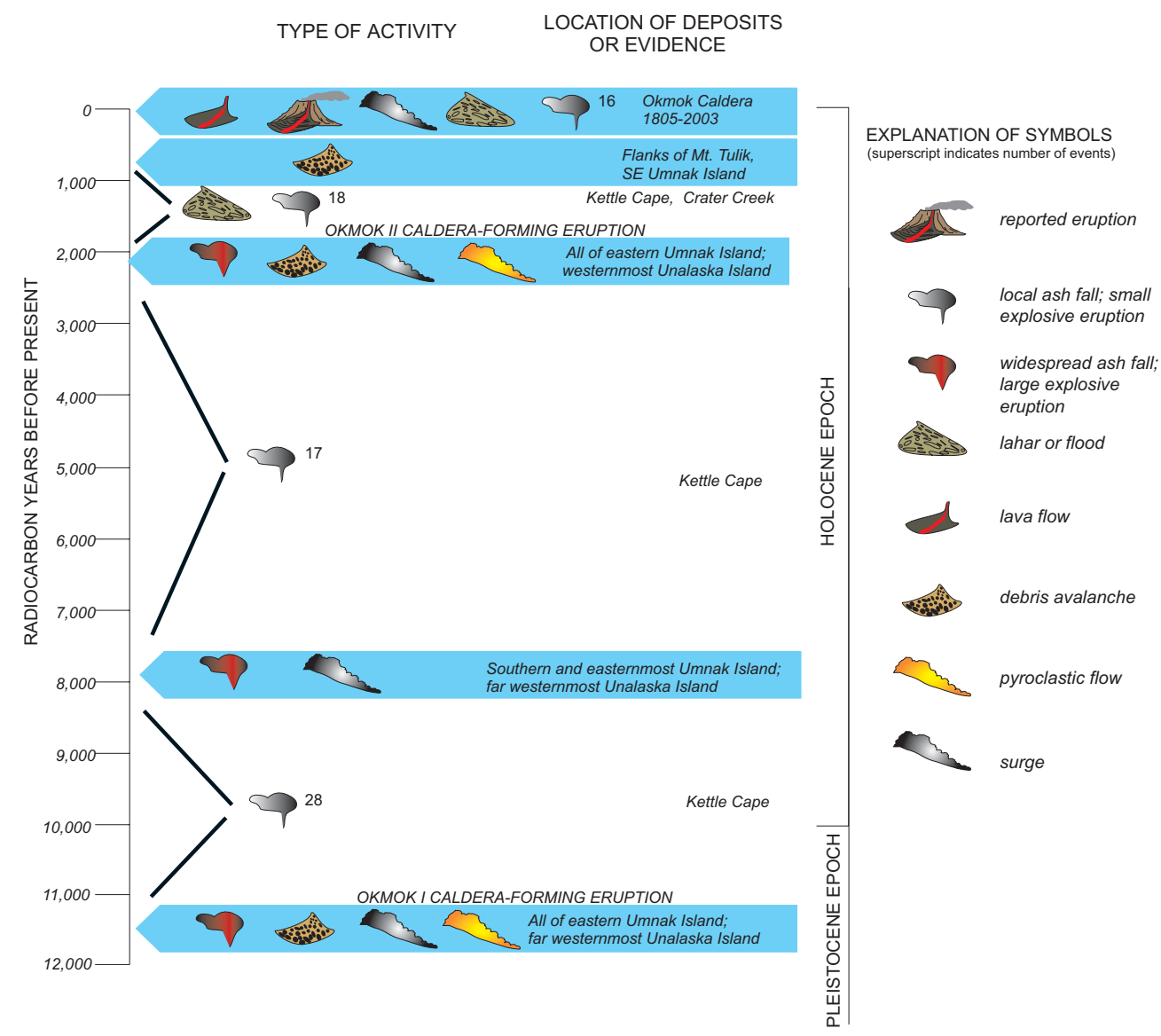

Figure 4. Prehistoric eruption history of Okmok Volcano, based on geologic mapping and stratigraphic studies. 
Volcano has been the site of volcanic eruptions for at least a million years, as indicated by radiometric dating of lava flows in deeply eroded cliffs on the flank of the volcano (Nye, 1990). However, most deposits produced by Pleistocene eruptions of Okmok Volcano have either been buried by younger volcanic deposits or removed by glacial erosion, particularly during past ice ages. As a result, a detailed record of volcanic activity at Okmok can be reconstructed only since the end of the last ice age (i.e., during the last 12,000 years).

The oldest deposits of Okmok Volcano that postdate the last ice age record a complex series of very large eruptions culminating in the development of a summit caldera (fig. 5). This late Pleistocene-early Holocene eruption generated voluminous deposits with compositions ranging from rhyodacite (70 wt. \% SiO2) to basaltic-andesite (54 wt. \% SiO2). It produced broadly synchronous welded pyroclastic flows, thick surge deposits, and debris avalanche deposits that together are as much as 100 meters thick on the northern flanks of Okmok Volcano. Pyroclastic flows and surges produced during these eruptions traveled to the coast and far out to sea around the volcano. The most distant deposit preserved on land was produced by a flow that crossed the waters of 7-kilometer-wide Umnak Pass to the westernmost part of Unalaska Island, traveling at least 21 kilometers from the vent. Surge deposits from this eruption also crossed Mt. Idak (fig. 2), climbing over a 200-meter scarp at a distance of 15 kilometers from the caldera rim. A debris avalanche also occurred at this time, but the debris avalanche deposits are very poorly preserved. The debris avalanche, found only on the north flank of the volcano, probably occurred during collapse of the former summit during the creation of the large caldera. Radiocarbon dates from directly beneath the pyroclastic flow deposits from this first caldera-forming eruption on westernmost Unalaska Island, and dates associated with distal volcanic ash deposits from these eruptions found near the city of Unalaska 100 kilometers to the east (Bean, 1999), both indicate the first calderaforming eruption occurred about 12,000 years ago.

Sparse outcrops preserve the history of volcanic eruptions between about 12,000 and 2,000 years ago when another enormous caldera-forming eruption occurred at Okmok Volcano. The most complete record was found at Kettle Cape on the south flank of the volcano, where a volcanic cone is mantled with a thick section of pyroclastic deposits (fig. 6). At least 43 volcanic ash layers are intercalated in non-volcanic sediment in a sequence deposited between an organic soil (deposited at least 8,600 years ago) and the 2,000-year-old pyroclastic flow, suggesting such explosive eruptions occurred on average every 150 years during this time interval. Many additional eruptions almost certainly
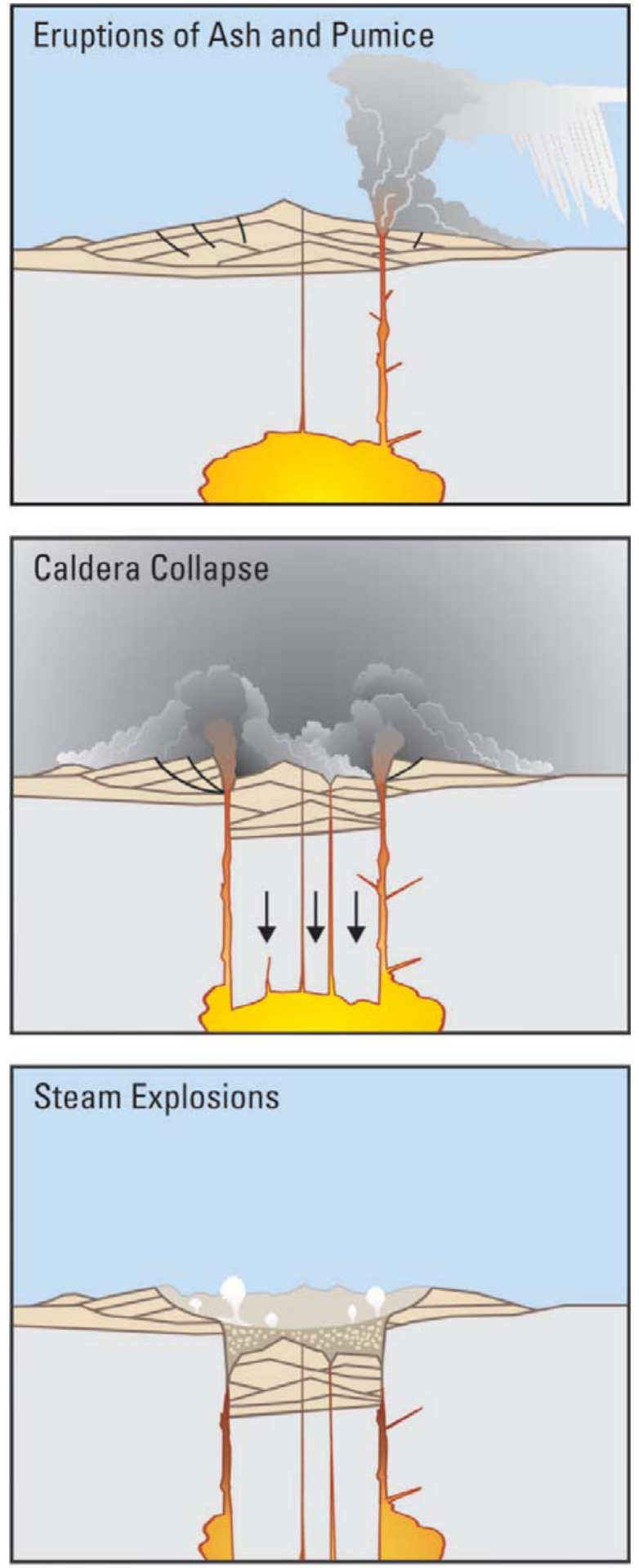

Figure 5. Simplified sketch showing the development of a caldera. Modified from Klimasauskas and others, 2002. 
occurred, some of which were not large enough to affect this site, located 15 kilometers from the caldera, as well as others whose ash deposits were dispersed by synoptic winds away from this side of the volcano. The largest historic ash fall deposit in this area dates to 1958, and is as much as several centimeters thick. More than a dozen of the ash fall deposits preserved at Kettle Cape are comparable in thickness to the historical 1958 tephra fall, suggesting eruptions of Okmok as large as or larger than the 1958 eruption have occurred repeatedly during the last 8,600 years, along with many more smaller eruptions.

At least four significant eruptions of mafic scoria ( 54 wt. \% SiO2; Wong, 2004) occurred during the time period between the older and younger caldera-forming eruptions and these are mainly found to the northeast and south of Okmok caldera. These units are poorly understood, yet contain evidence for explosive interactions between external water and magma, producing phreatomagmatic deposits. The most extensive of these is described in Wong (2004), and consists of thick deposits of scoria and rock fragments deposited to the south and east of the present caldera. In addition, a thin surge bed containing incinerated plant remains occurs between deposits of the first and second caldera-forming eruptions on southern Unalaska Island. This surge, which is associated with a thick tephra-fall deposit and is also locally exposed on the east end of Umnak Island, demonstrates that highly mobile pyroclastic flows capable of traveling across water to distances of 20 kilometers and more from Okmok Volcano can be generated independently of caldera-forming eruptions. Radiocarbon dates from charcoal in the surge suggest it occurred about 8,000 years ago, similar in age to an ash deposit near Nikolski, which was attributed to a large eruption of Okmok (Black, 1974).

In addition to eruptions within the caldera, more than 20 small cinder cones and lava flows occur high on the

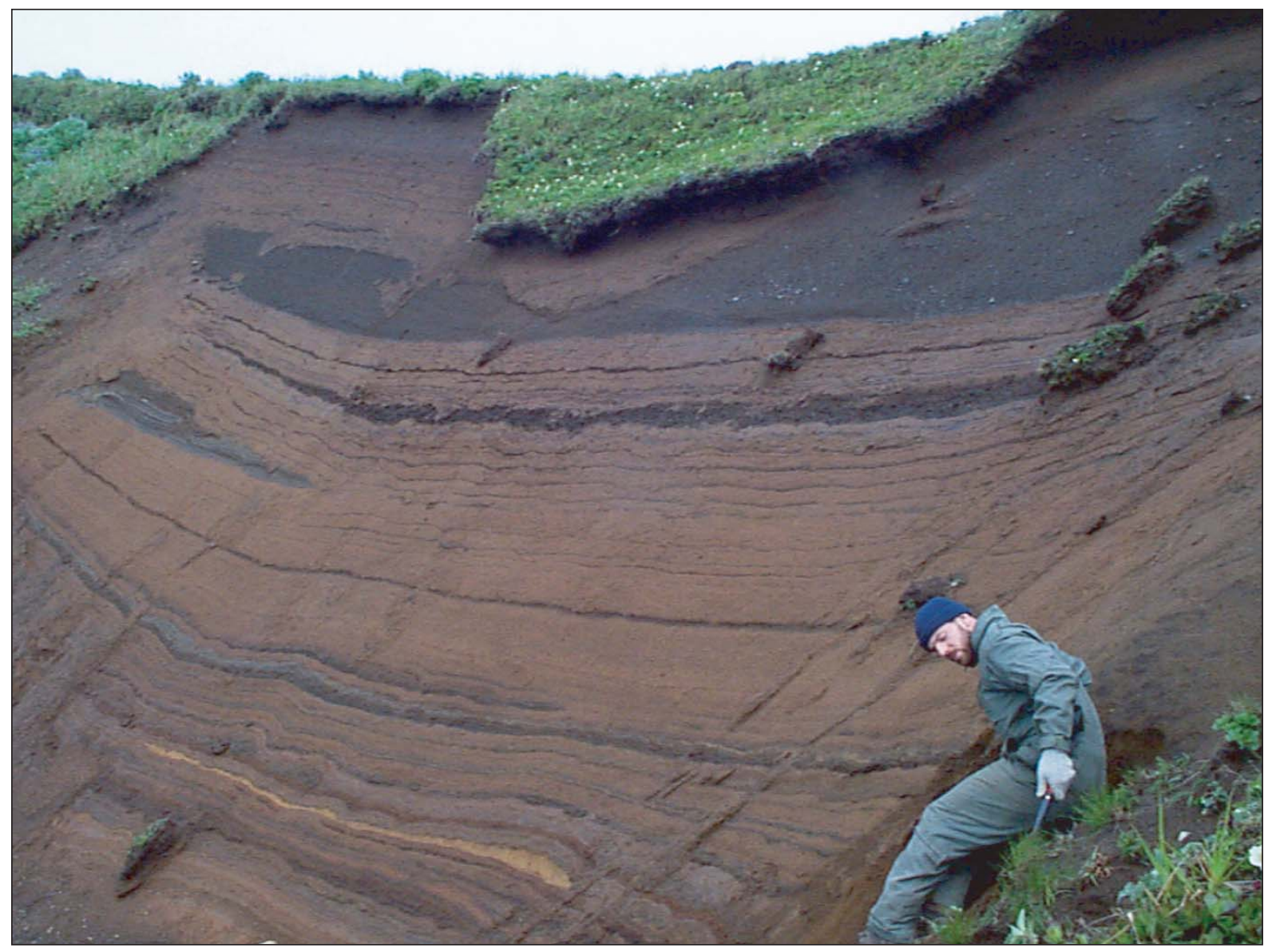

Figure 6. Prehistoric volcanic ash deposits from Okmok Volcano preserved near Kettle Cape, about 10 kilometers south of the caldera rim. More than 60 separate tephra layers at this site record repeated explosive eruptions of Okmok during the last 8,600 years. The irregular layer of scoria as much as $60 \mathrm{~cm}$ thick near the top of the section was produced by the caldera-forming eruption of Okmok about 2000 years ago. Photo by Jim Begét, Alaska Volcano Observatory. 
upper north and northeastern flanks of the volcano and around the caldera rim, and at least five flank cones lie on the southwest flank of the volcano. These features are relatively uneroded and most are likely post-glacial in age and also pre-date the most recent caldera-forming eruption and so are less than 12,000 years old. The largest flank eruption produced a 200-meter-high lava spatter cone and a voluminous lava flow that forms cliffs at Cape Aslik (fig. 2). The lava flow covers more than 15 square kilometers on the west flank of the volcano, involves about 0.5 cubic kilometers of lava, and is locally buried by tephra produced during the younger caldera eruption about 2,000 years ago.

The second large caldera-forming eruption produced a pyroclastic flow deposit that buried the older pyroclastic flow and almost all other older volcanic and non-volcanic sediments on all flanks of Okmok Volcano. The deposits of this caldera-forming eruption are as much as 80 meters thick near the caldera rim, and 30 to 40 meters thick at some coastal exposures (fig. 7). The most distal deposits preserved on land are found $25 \mathrm{ki}-$ lometers to the southeast across Umnak Pass on southern Unalaska Island. Sea cliff exposures on the north, east, and south flanks of the volcano show where the pyroclastic flow advanced into the sea in these directions. New radiocarbon dating on plants found buried and incinerated at the base of the pyroclastic flow indicates the second caldera-forming eruption occurred about 2,050 \pm 50 14C years ago (Begét and Larsen, 2001). This eruption generated a tsunami which affected the westernmost part of Unalaska Island.

Following the caldera-forming eruptions, frequent small eruptions have occurred up to the present time, many of which were explosive (fig. 4). Byers (1959) identified extensive lava flows and distinguished eight separate volcanic cones of post-caldera age within the caldera, and ongoing fieldwork has identified several more vents. Tephra deposits, preserved at many sites on the flanks of the volcano, provide a record of those explosive eruptions large enough to have a significant impact on areas outside the caldera. One of the most detailed records of explosive volcanism occurs at Kettle Cape, where 24 tephra layers were deposited since the 2,000-year-old pyroclastic flow (fig. 6). This record suggests that explosive eruptions large enough to put a centimeter or more of ash in coastal areas around Okmok

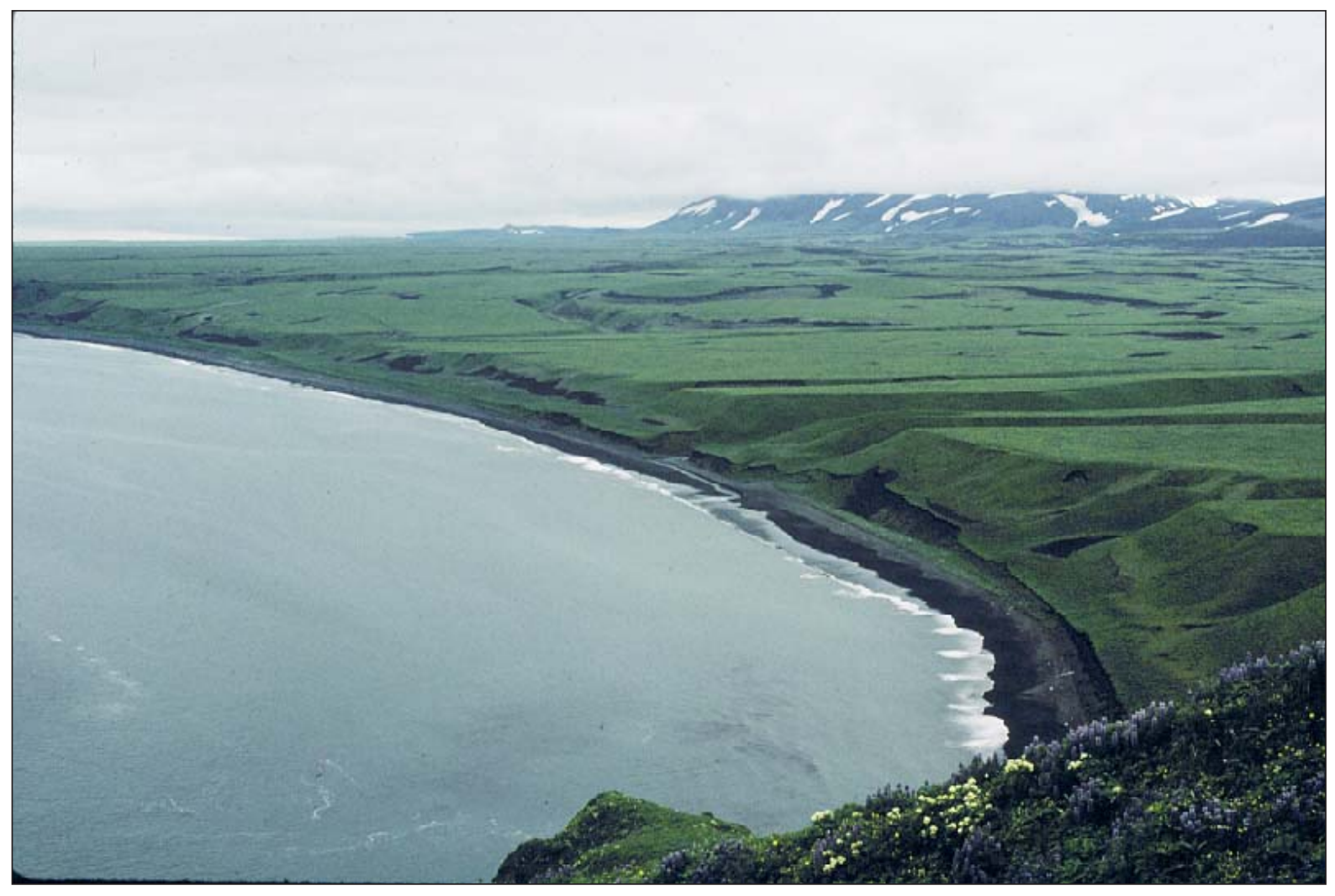

Figure 7. The flanks of Okmok Volcano are deeply buried by two thick pyroclastic flows produced by two huge caldera-forming eruptions 2,000 and 12,000 years ago. The flat-topped surfaces of the most recent pyroclastic flows have been deeply incised by rivers during the 2,000-year-long period since the last caldera-forming eruption. 
Volcano since the second caldera-forming eruption have occurred approximately every 75 years over the last two millennia. This frequency is about twice as high as the recurrence interval estimated for explosive eruptions for the six millennia prior to the 2,000-year-old calderaforming eruptions, suggesting that a possible increase in eruption frequency and/or explosivity began after the second caldera-forming eruption.

Numerous post-caldera (younger than 2,000 years) pyroclastic flow and surge deposits are found associated with the young tuff cones within the caldera, and distal pyroclastic flow and surge deposits also occur on the west, north, and northeast flanks of Okmok Volcano as far as 14 kilometers from the caldera rim. The thickest set of young surge deposits outside of the caldera occurs on the west flank of Okmok about 8 kilometers from the caldera rim, where deposits of fine-grained surge beds containing incinerated plant remains and abundant accretionary lapilli are more than 6 meters thick. These deposits were emplaced about 1,500 years ago.

There is evidence that a lake filled the caldera to a depth of 150 meters over a period of several hundred years. The caldera lake drained catastrophically after failure of part of the caldera rim. The resultant flood caused deep erosion of the landscape on the north side of the volcano (Wolfe, 2001). Lahar deposits are present at low elevations in many of the stream valleys draining the volcano, and can be traced up to 12 kilometers down valley from the caldera rim. At most sites only a single lahar deposit is exposed, but at least three lahars, each more than 1 meter thick, occur in sea cliffs near the mouth of Ginger Creek on the west flank of the volcano, and are exposed intermittently for more than 2 kilometers along the beach. Radiocarbon dates suggest these lahars were emplaced 300 to 400 years ago.

A debris avalanche deposit up to 10 meters thick overlies the 2,000-year-old pyroclastic flow surface on the southeast flank of Okmok Volcano. This debris avalanche originated on Tulik Volcano, covers 20 square kilometers, and the resulting deposit can be traced more than 6 kilometers down slope to the shore of the Pacific Ocean.

\section{THE HISTORICAL RECORD OF VOLCANIC ERUPTIONS}

While eruptions at Okmok have been observed by native Aleuts for thousands of years, the earliest written records date only to the time of Russian exploration and colonization in the 18th and 19th centuries. The remote location of Okmok Volcano meant that until World War II, most observations of volcanic eruptions could be made only when ships or airplanes were passing near Okmok, and only at times when the weather was clear.
Such records undoubtedly underestimate the actual number of eruptions.

Okmok Volcano is known to have erupted at least 16 times since the early 1800s, when Russian explorers and traders first began keeping written records of events in the Aleutians (Miller and others, 1998; Grey, 2003) (table 1). Some distant observers reported eruptions at Tulik Volcano, a high cone on the southeast flank of Okmok Volcano, but we found no evidence of recent eruptions from this site and we believe all such reports were actually sightings of ash clouds erupted from within the lower and much less visible caldera. Eruptions in the caldera during the last 200 years have been both effusive and explosive. The earliest records are mainly of ash clouds that in some cases rose to 10 kilometers or more above sea level, while the better documented eruptions since World War II are known to have consisted both of explosive episodes and coeval eruptions of effusive lava flows (table 1). All of the eruptions since World War II have occurred from Cone A, but other vents may have been active between 1800 and 1945 . The historical record of eruptions suggests that during the last 200 years, an eruptive episode occurred on average every 12 years. During the 20th century, when the record is probably more complete, 11 eruptions are recorded since 1930, corresponding to an average of one eruption every seven years. These eruption frequencies cannot be directly compared to the geologic record of prehistoric events based on volcanic ash deposits preserved on the flanks of Okmok Volcano, since most of the historical events were too small to be preserved as geologic deposits.

The largest eruption of Okmok Volcano in historical times occurred in 1817, and reportedly deposited more than 20 centimeters of ash on the town of Unalaska, 100 kilometers to the northeast and produced a "flow of ashes" that destroyed an Aleut village at Cape Tanak on Umnak Island (Grewingk, 1850). Byers (1959) thought the reported ash thicknesses at Unalaska may have been exaggerated, and after extensive searches we were unable to find a significant ash deposit of this age either near the town of Unalaska, or even on southwest Unalaska Island only 20 kilometers to the east. However, we did identify young tephra-fall and surge deposits from Cone B, which are as much as 3 meters thick on the north rim of Okmok Volcano, and young lahars and flood deposits up to 2 meters thick along lower Crater Creek at Cape Tanak. Radiocarbon dates suggest these deposits date to the early 19th century, and are the deposits that buried the Aleut village during the large 1817 eruption (Wolfe and Begét, 2002). The flood deposits were generated when a small lake within the caldera drained catastrophically. The lake had been dammed by lava flows from Cone B. 
Table 1. Historical eruption record of Okmok Volcano, compiled from multiple sources (Grey, 2003)

\begin{tabular}{|c|c|c|c|c|c|}
\hline Date & $\begin{array}{l}\text { Repose } \\
\text { (yr.) }\end{array}$ & $\begin{array}{c}\text { Vent }^{\mathrm{a}} \\
\text { (Cone) }\end{array}$ & $\begin{array}{l}\text { Type of } \\
\text { Eruption }\end{array}$ & Notes & References $^{b}$ \\
\hline $1805^{c}$ & - & $?$ & unknown & “eruption on Umnak” & $\begin{array}{l}\text { Langsdorff, } 1812 \\
\text { Hantke, } 1951\end{array}$ \\
\hline $\begin{array}{l}\text { Mar. } 1 \text { or } 2,1817 \\
\text { (to } 1820 \text { ?) }\end{array}$ & 12 & $\mathrm{E} ? \mathrm{~B}$ ? & explosive & $\begin{array}{l}\text { ash reported at } \\
\text { Unalaska, destroyed } \\
\text { Aleut village at Cape } \\
\text { Tanak }\end{array}$ & $\begin{array}{l}\text { Luetke, } 1836 \\
\text { Veniaminov, } 1840 \\
\text { Grewingk, } 1850 \\
\text { Hantke, } 1951 \\
\text { Wolfe, } 2001\end{array}$ \\
\hline 1824-1830 & 7 & $\mathrm{~B}$ ? & ash, lava? & fissure? & Grewingk, 1850 \\
\hline 1878 & 48 & $\mathrm{~A}$ ? & unknown & $\begin{array}{l}\text { formation of new } \\
\text { crater in caldera }\end{array}$ & Hantke, 1951 \\
\hline 1899 & 21 & A & explosive & ash to W\&S of caldera & Dunn, 1908 \\
\hline Mar. 21-May 13, 1931 & 32 & A? & ash, lava? & “smoke” & $\begin{array}{l}\text { Jaggar, } 1931 \\
\text { Coats, } 1950\end{array}$ \\
\hline 1936 & 5 & A & ash & “smoke” & Coats, 1950 \\
\hline 1938 & 2 & A & unknown & & Coats, 1950; SS \\
\hline June 1943 & 5 & A & ash & very brief eruption & Keller, 1991 \\
\hline June 4-Dec. 1945 & 2 & A & lava and ash & $\begin{array}{l}\text { observed by USGS } \\
\text { geologists and Army } \\
\text { personnel at Ft. Glenn }\end{array}$ & $\begin{array}{l}\text { Byers and others, } 1947 \\
\text { Robinson, } 1948\end{array}$ \\
\hline Aug. 14-25, 1958 & 13 & A & lava and ash & $\begin{array}{l}\text { large lava flow, pilot } \\
\text { report published years later }\end{array}$ & ADN; BVE, 1984 \\
\hline $\begin{array}{l}\text { Oct. 15, 1960- } \\
\text { April 15, } 1961\end{array}$ & 2 & A & ash & $\begin{array}{l}\text { ash at Chernofski ranch } \\
\text { on Unalaska Island, } \\
\text { activity intermittent }\end{array}$ & $\begin{array}{l}\text { ADN; BVE, } 1986 \\
\text { Holmes, 1994; SS }\end{array}$ \\
\hline Mar. 24, 1981 & 20 & A & ash & pilot report & Miller and others, 1998 \\
\hline July 8, 1983 & 2 & A & ash, $\mathrm{SO}_{2} / \mathrm{H}_{2} \mathrm{~S}$ ? & $\begin{array}{l}\text { pilot report, satellite } \\
\text { observation }\end{array}$ & BVE, 1986; SI, 1983 \\
\hline $\begin{array}{l}\text { Nov. 18, 1986- } \\
\text { Feb. 26, } 1988\end{array}$ & 3 & A & ash & intermittent activity & $\begin{array}{l}\text { SI, 1986, 1987, 1988; } \\
\text { SS }\end{array}$ \\
\hline Feb. 11-Apr. 1, 1997 & 9 & A & $\begin{array}{l}\text { lava, ash, } \\
\text { fountaining }\end{array}$ & $\begin{array}{l}\text { eruption confirmed by } \\
\text { pilot reports, satellite } \\
\text { imagery, and on-site } \\
\text { observation }\end{array}$ & $\begin{array}{l}\text { SI, } 1997 \\
\text { Miller and others, } 1998 \\
\text { McGimsey and Wallace, } \\
\quad 1999\end{array}$ \\
\hline
\end{tabular}

${ }^{a}$ Vent from which eruption issued is given where known (nomenclature of Byers, 1959), marked by ? where uncertain and inferred.

bADN, Anchorage Daily News; BVE, Bulletin of Volcanic Eruptions; SS, Simkin and Siebert, 1994; SI, Smithsonian Institution, Scientific Event Alert Network (1983-1988), Bulletin of the Global Volcanism Network (1997)

c1805 eruption not corroborated by Langsdorff (1812) 
Sometime after the 1817 eruption, activity shifted to the site of Cone A (fig. 8). A significant explosive eruption occurred at Cone A in 1945, beginning with a large earthquake that was followed a few days later by explosive eruptions that repeatedly sent ash up to an altitude of 3,000 meters. This eruption continued for about six months, with additional episodes of ash emissions, and the emplacement of a 6.5-kilometer-long lava flow on the caldera floor. Ballistics as much as 1 meter across were blasted from Cone A, and the cone itself grew in height by about 30 meters (Miller and others, 1998).

A similar eruption from Cone A occurred in 1958, and although not as well documented, apparently again involved multiple explosive eruptions of scoria and the emplacement of extensive lava flows within the caldera. Tephra from the 1958 eruption buried vegetation and roads on the south flank of the volcano to a depth of 10 centimeters at a distance of 9 kilometers from the vent, while the lava reached 8 kilometers from the vent and formed a dam that impounded a new lake that eventually covered 1.3 square kilometers in the northeastern part of the caldera.
Eruptions of steam and ash in 1981, 1983, and 1987 were not closely observed, but also probably occurred at or near Cone A, and resulted in ash and steam reaching elevations of 5,500 meters above mean sea level. A small pyroclastic flow reportedly was erupted from Cone A in 1987 (Miller and others, 1998).

The most recent series of eruptions occurred at Cone A during 1997, and lasted about eight months. As during the 1945 and 1958 eruptions, explosive eruptions sent ash clouds high above the volcano, several times reaching elevations of 5,000 meters asl and once to 9,000 meters asl. This eruption was also accompanied by the eruption of a lava flow that reached 6 kilometers from the vent, burying most of the 1958 lava flow.

\section{POTENTIALLY HAZARDOUS VOLCANIC PHENOMENA AT OKMOK VOLCANO}

Volcanic eruptions produce a wide variety of phenomena (fig. 9) that are potentially threatening to people

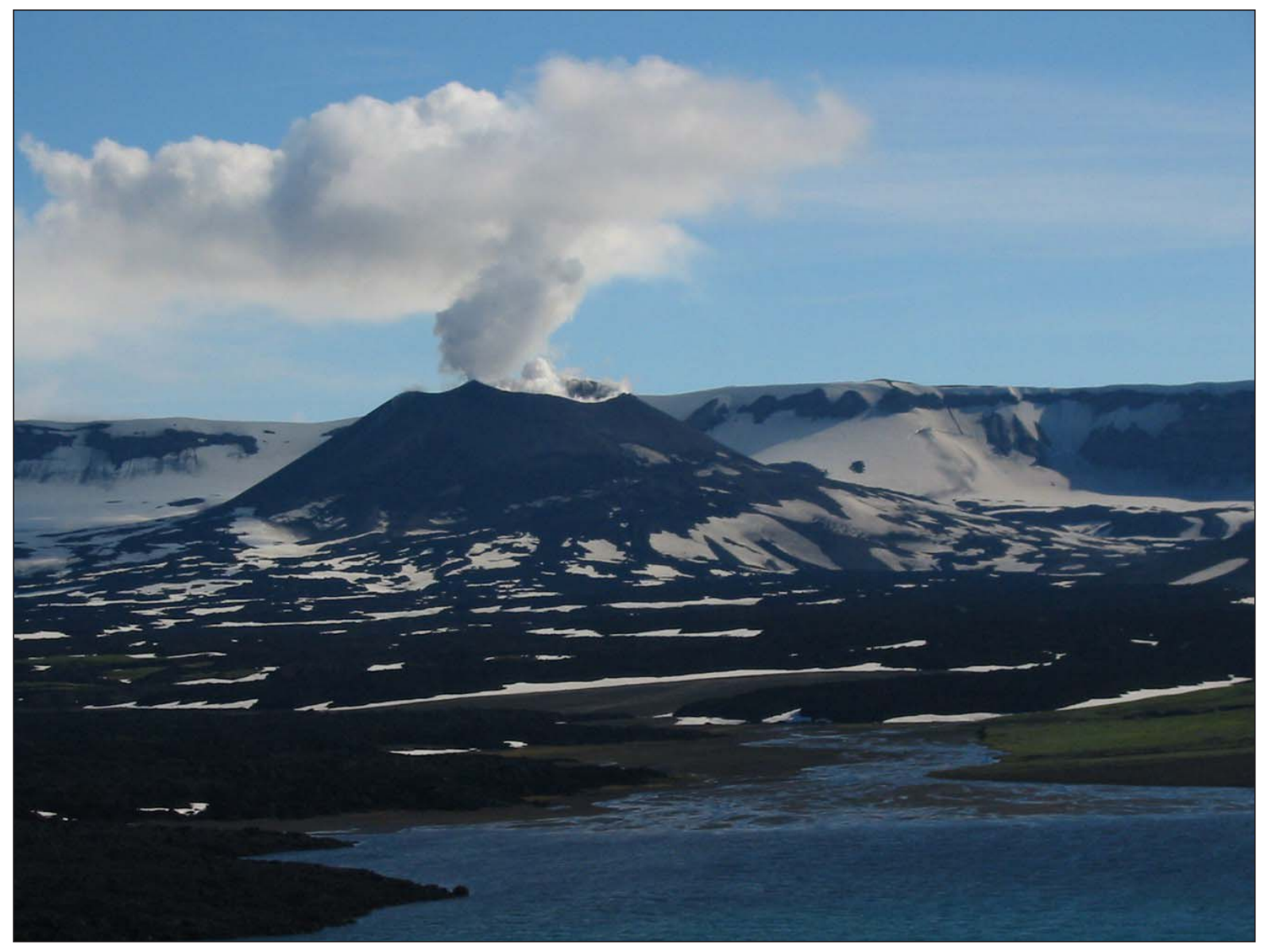

Figure 8. Steam rises from Cone A, the currently active vent within the caldera at Okmok Volcano. Photo by Jeff Freymueller, University of Alaska Fairbanks Geophysical Institute, 2002. 
and property (Scott, 1989; Blong, 1984). Modern scientific instruments and monitoring techniques may give warning of the beginning of an eruptive episode, but the size and duration of future eruptions are not always possible to predict.

In this report we discuss hazardous volcanic phenomena that may accompany future eruptions of Okmok Volcano, and evaluate the extent of the areas at risk around the volcano. All of the hazardous phenomena discussed become more energetic and dangerous at closer distances to the volcanic vent, and decrease gradu- ally in intensity with distance from the volcano. It is important to realize that eruptions are dynamic, and small, localized eruptions can sometimes change quickly into large volcanic eruptions that may endanger people and property at distances of 20 kilometers or more from the volcano. Multiple hazardous processes can occur simultaneously, and can start and stop independently of one another. The areas at risk during future eruptions of Okmok Volcano will vary in response to the magnitude and style of the eruptions, as well as weather and local wind direction.

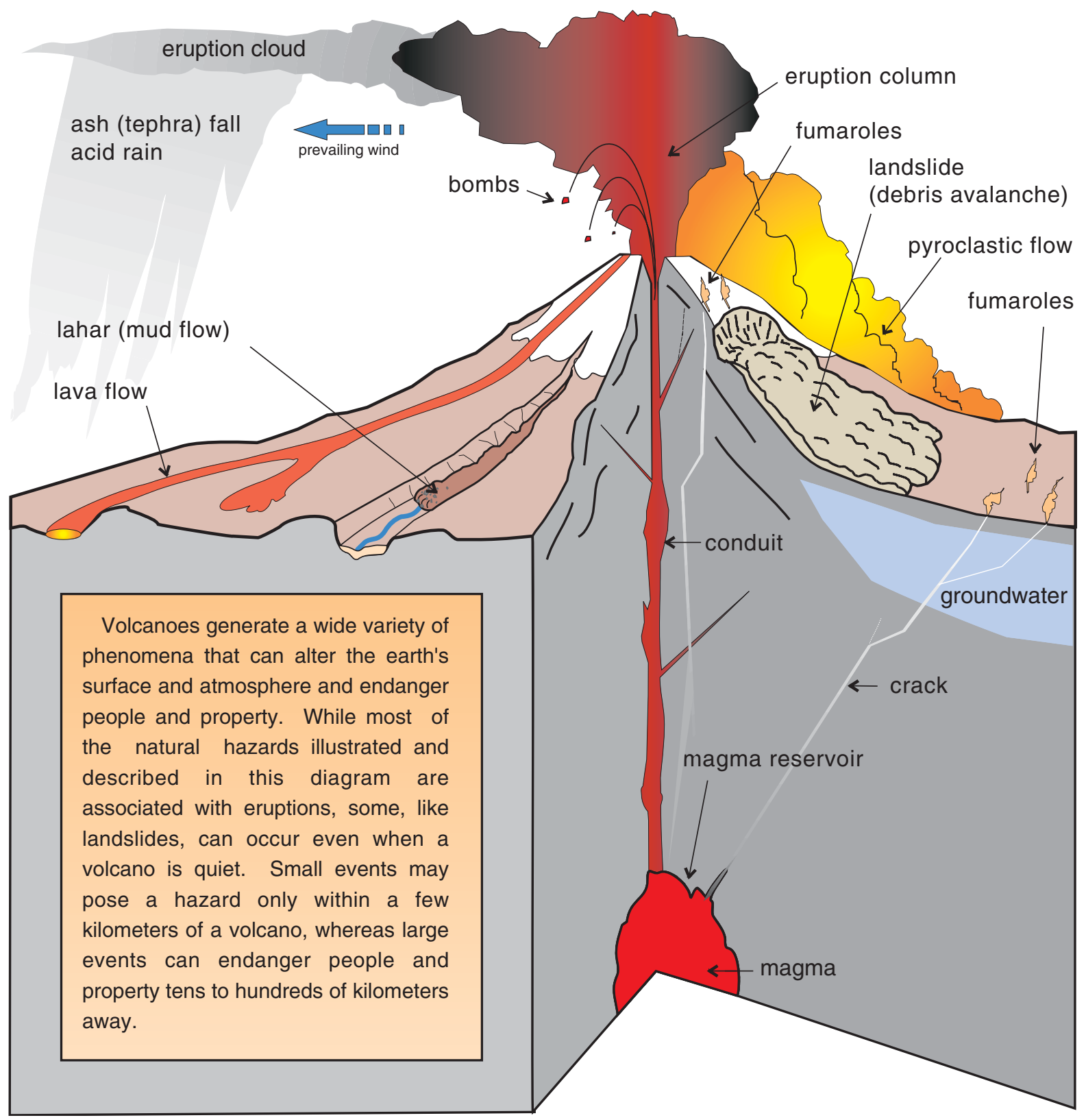

Figure 9. Sketch of a stratovolcano and simplified illustrations of various volcanic hazards that typically accompany eruptions, from U.S. Geological Survey Fact Sheet 002-97 (Myers and others, 1997). 
At Okmok Volcano, the available topographic base maps are preliminary and incomplete, and because our geologic studies are only preliminary, the geographic extents and limits of hazard zones should be treated as approximations. Also, the hazards associated with many of the phenomena are themselves sensitive to local topography, so the impacts may vary greatly within specific hazard zones. For instance, floods and lahars might bury areas at low elevation along stream drainages, while some adjacent areas at high elevation may be safe and unaffected.

The extents of hazard zones on the hazard map are based on the geologic map of eastern Umnak Island (Byers, 1959) and on our ongoing geologic investigations and mapping, which have revealed the distribution of volcanic deposits produced during prehistoric and historical eruptions. Both historical and prehistoric eruptions of Okmok Volcano produced ash falls, pyroclastic flows, lava flows, debris avalanches, lahars, and floods that repeatedly impacted proximal areas near the volcano. Volcanic ash clouds, ash fallout, and pyroclastic flows and surges have occasionally reached areas more than 20 kilometers from the volcano. The 16 known eruptions that have occurred during the last 200 years provide a reasonable model for evaluating volcanic hazards for similar eruptions in the near future. Evidence of larger eruptions that occurred during the last 12,000 years form the basis for evaluating volcanic hazards that might accompany very large but infrequent eruptions of Okmok Volcano.

\section{PRINCIPAL VOLCANIC HAZARDS}

\section{Volcanic Ash Clouds}

The most significant hazard from future eruptions of Okmok Volcano is the generation and emplacement of volcanic ash clouds high into the atmosphere, where they may drift into the paths of passenger jets and other aircraft and cause potentially catastrophic damage.

During the last 200 years, explosive eruptions at Okmok Volcano have repeatedly produced ash clouds ascending from 3 to 20 kilometers above sea level. Ash clouds are produced when explosive eruptions generate columns of ash and hot gas that, in the case of extremely large eruptions, can ascend convectively to elevations of 40 kilometers (25 miles or 130,000 feet) above sea level. Ash clouds drift with the prevailing winds away from the volcano, carrying particles of pulverized volcanic rock ranging in size from microscopic to several centimeters in diameter. Ash clouds can maintain their buoyancy and integrity for days to weeks while traveling through the atmosphere for distances of hundreds to thousands of kilometers, depending on the size of the eruption. The particles of volcanic glass and other material carried by ash clouds are hazardous to jet engines, windows, air intakes, electronics, and other parts of aircraft that fly through them in areas downwind from the volcano (Swanson and Begét, 1994; Casadevall, 1994).

While no airplanes are known to have been affected by the 1997 tephra eruptions at Okmok Volcano, the type and extent of hazards that might accompany future ash eruptions at Okmok Volcano are suggested by the results of encounters between airplanes and ash following eruptions at other Alaskan volcanoes. During the 1976 eruption of Augustine Volcano, for instance, ash clouds reached 12 kilometers above sea level, and drifted away from the volcano toward the east. At least five jet aircraft flew through the ash clouds and sustained abrasion on windshields, wings, landing gear, and other parts of the planes. The ash clouds were tracked southeastward over the Pacific Ocean and Canada, and reached as far south as Arizona and as far east as the Great Lakes and Virginia. In 1986 ash clouds from Augustine Volcano again reached at least 12 kilometers above sea level on four occasions; one jet aircraft flew through an ash cloud, and air traffic was disrupted at several Alaska airports for several weeks (Waythomas and Waitt, 1998). In 1989-90, several explosive eruptions of Redoubt Volcano sent ash to at least 12 kilometers above sea level, and on December 15, 1989, a Boeing 747 flew into an ash cloud 240 kilometers northeast of Anchorage International Airport and lost power in all four jet engines. The plane, with 231 passengers aboard, lost more than 3,000 meters of altitude before the flight crew was able to restart the engines (Casadevall, 1994). After landing, it was determined the airplane had suffered about $\$ 80$ million in damage (Waythomas and others, 1998; Brantley, 1990).

The magnitude of the ash cloud hazard during future eruptions of Okmok Volcano depends on the characteristics of the eruption, including the elevation and rate of ascent of the ash cloud, the total amount of sulfur and other gases, the concentration, size, and chemical composition of the ash particles, and the wind direction (fig. 10). Large eruptions of ash clouds by Okmok Volcano are likely to affect air travel and operations at the Dutch Harbor airport, and are potentially hazardous to air traffic operating in other areas over the eastern Aleutian Islands and surrounding areas of the northern Pacific Ocean (fig. 11).

\section{Volcanic Ash and Bomb Fallout}

During explosive eruptions, ash, pumice, large volcanic bombs, and rock debris are blasted upward from the vent on various trajectories, and then rain out 


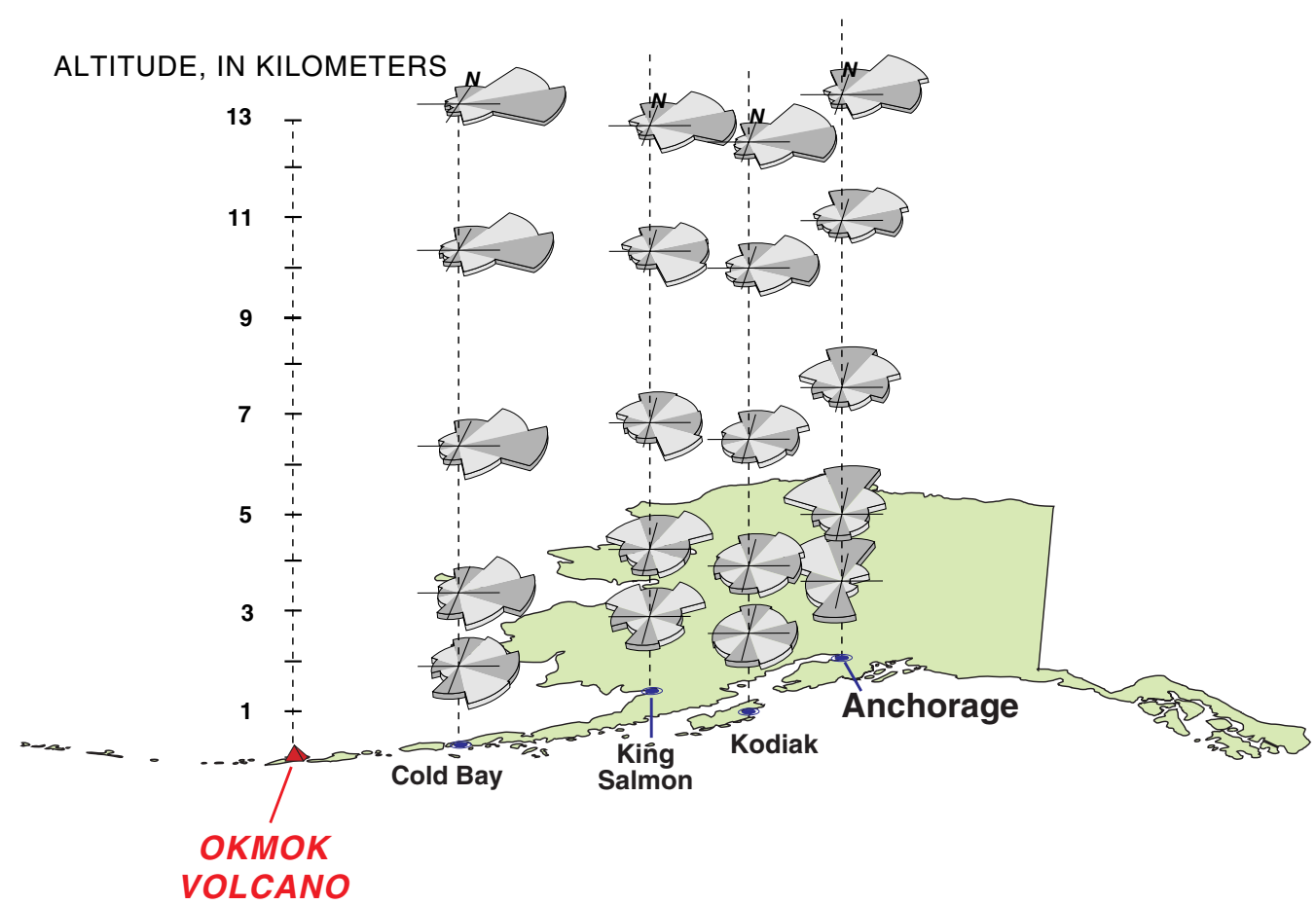

Figure 10. Average wind direction over the southwestern Alaska Peninsula and Cook Inlet. During future eruptions of Okmok Volcano, volcanic ash will drift with the wind, most likely toward the northeast, east, or southeast. The lengths of the sections on the windrose diagrams are proportional to wind frequency determined by annual percent. Original data are from the National Climatic Data Center, National Oceanic and Atmospheric Administration.

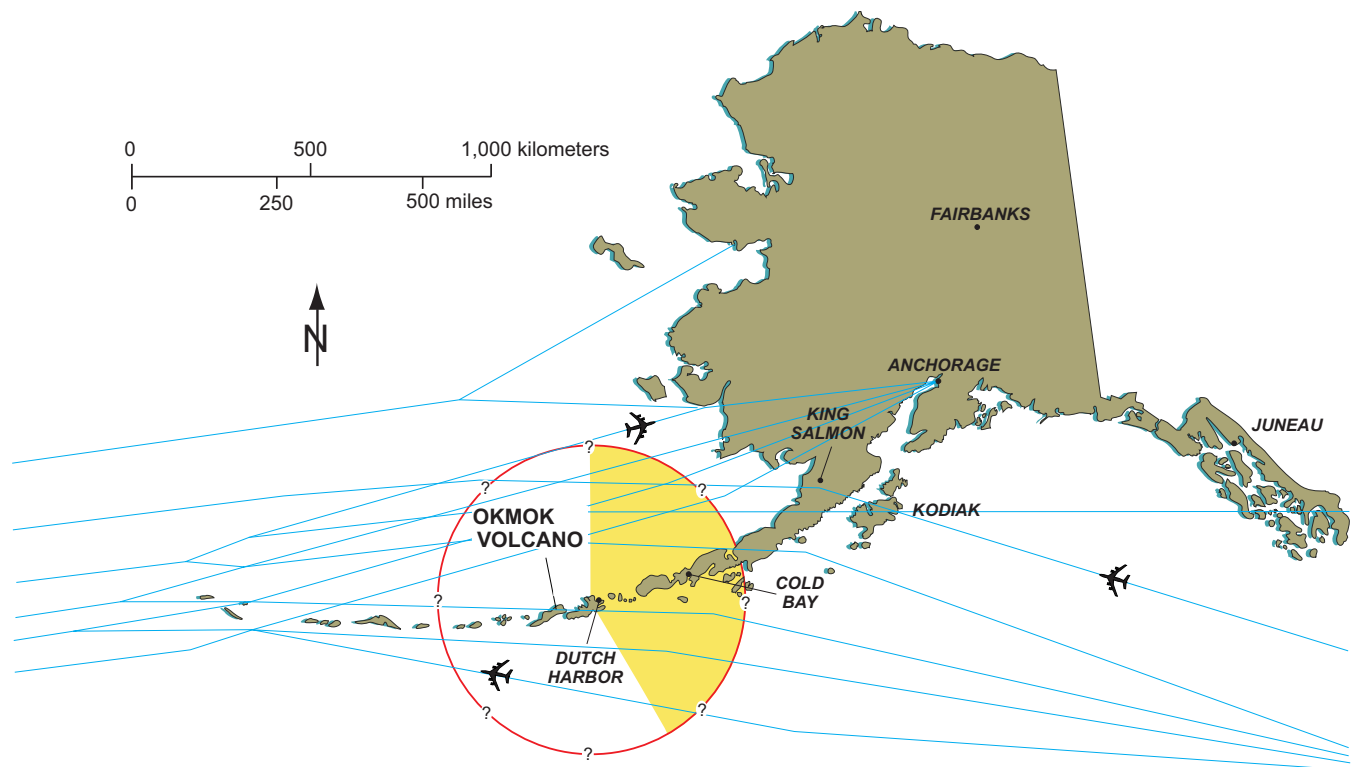

Figure 11. Selected representative flight paths of commercial freight and passenger airlines crossing the North Pacific. Future explosive eruptions of Okmok Volcano may inject ash as high as 10,000 to 20,000 meters (30,000-65,000 feet) into the atmosphere, causing disruption of transPacific flights. The exact area of ash fallout will depend on synoptic weather conditions and wind directions, but because of prevailing wind patterns ash is most likely to be dispersed east of the volcano (shaded area). Ash fall during small eruptions will be restricted to the immediate vicinity of the volcano and surrounding parts of Umnak Island, with fallout of large blocks and bombs restricted to areas within 5 kilometers of the active vent. 
ballistically around the volcano (fig. 12). Small episodic explosions such as these are characteristic of Strombolian activity. During such eruptions large volcanic bombs typically fall no more than a few kilometers from the vent, although bombs ejected in unusually large explosive eruptions may reach areas 10 kilometers or more away. Because the area close to Okmok Volcano is uninhabited, the risk from volcanic bombs and other ballistics is low except to humans and low flying aircraft that might come near the active vent during an eruption.

While the hazards associated with large ballistics are restricted to the vicinity of the vent, finer-grained volcanic ash will fall out from ash clouds as they drift away from erupting volcanoes, and can affect areas tens or even hundreds of kilometers away from the vent. During ash fallout, the sky typically darkens, and visibility may be reduced to only tens of meters, disrupting all types of activities. Falling volcanic ash accumulates on the roofs of buildings, and the weight of a thick ash fall may cause roofs and lightly constructed buildings to collapse. The weight of volcanic ash is about 12 times greater than an equivalent depth of snow. Because ash is porous, it can absorb significant amounts of water, and the total weight load on a roof may be significantly increased if the falling ash is mixed with rain or snow, or if it rains on the ash after deposition (Blong, 1984). This hazard can be reduced by shoveling ash off structures before it accumulates to dangerous thicknesses.
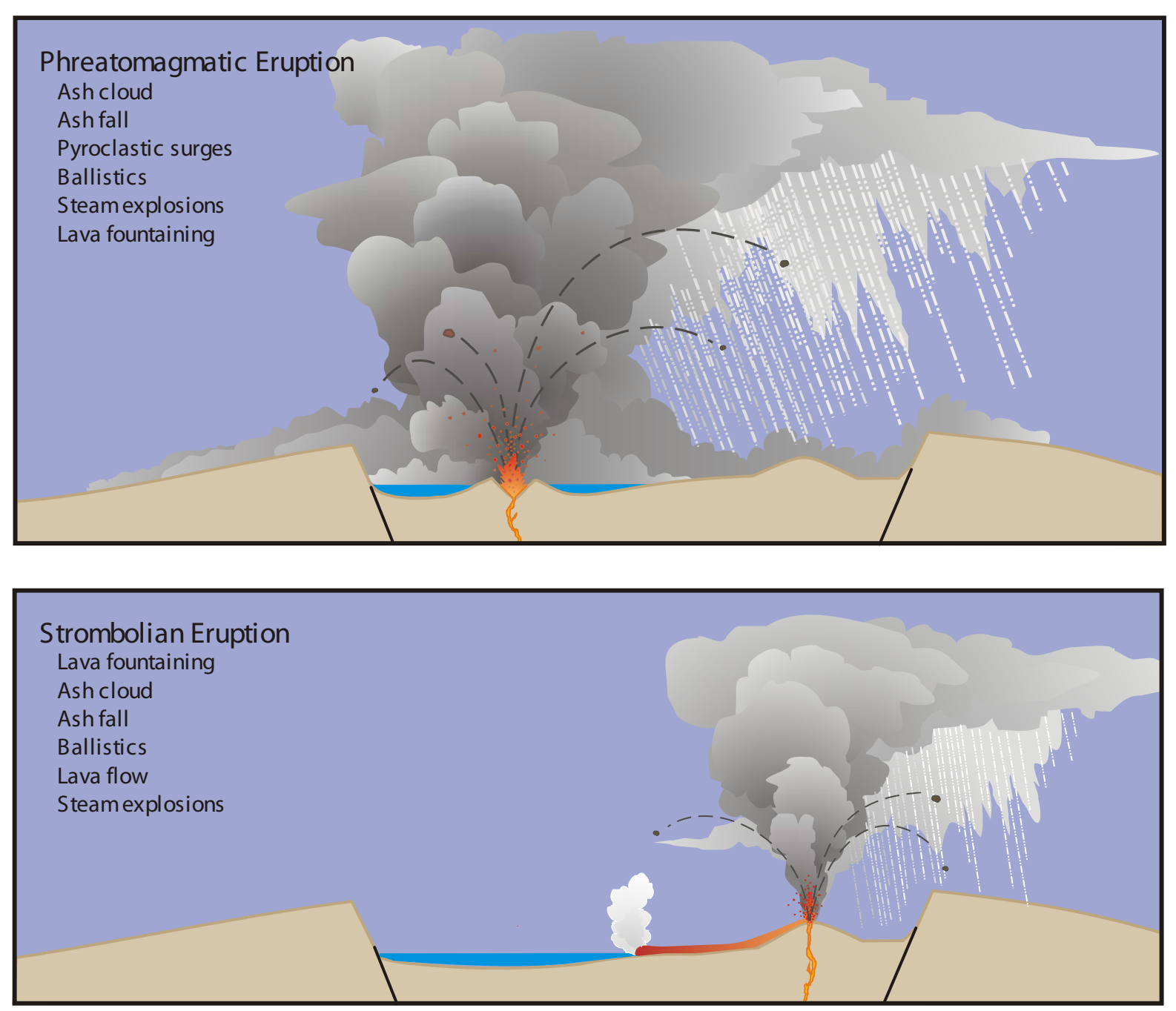

Figure 12. Sketch of phenomena that accompany typical explosive eruptions at Okmok Volcano. Eruptions from Cone A during the 20th century were primarily Strombolian, and areas outside the caldera were affected only by ash clouds and ash falls. However, some earlier eruptions such as the 1817 event at Cone B involved magma interactions with lake water, and these hydrovolcanic explosive eruptions generated pyroclastic surges that sometimes overtopped the caldera rim and traveled down the slopes and drainages around Okmok at very high velocities. 
A wide range of mechanical and electrical systems can be affected by airborne ash during even relatively thin ash fallout of 1 to 2 centimeters. Ash fallout can affect the cooling and electrical systems of automobiles and other internal combustion engines. Equipment in hospitals, power plants, pumping plants, and factories may be damaged. Ash falls can cause short circuits, and disrupt telephone circuits and other communications systems. Thicker ash fallout can clog water and sewer systems (Blong, 1984; Scott, 1989).

Ash fallout can cause health problems in humans. People with respiratory problems can experience breathing difficulties during very minor ash fallout. Even healthy people may find prolonged exposure to atmospheric dust during sustained ash fallout irritating. It is possible for volcanic ash falls to be associated with harmful gases, although such events are rare. The health effects of ash fallout on humans can be mitigated by advising people with respiratory problems to stay indoors during ash fallout, and by the use of respirators, filters, or wet cloths over the mouth and nose for people who must work outdoors.

If future eruptions at Okmok Volcano are similar in size to the historical eruptions of the last 200 years, the areas most likely to be affected by significant ash fallout will be restricted to the flanks of the volcano and nearby areas of Umnak Island and adjacent Unalaska Island. However, geologic studies show that more powerful eruptions have occurred on several occasions during the last 12,000 years, in one case depositing pumice and ash more than 100 centimeters thick in areas 20 kilometers from the volcano. A recurrence of a very large eruption at Okmok Volcano would destroy buildings in the Fort Glenn area, and might result in significant accumulations of ash as thick as several centimeters or more at distances more than 100 kilometers from Okmok Volcano. Such an eruption might affect operations at the airport and other facilities in the cities of Dutch Harbor and Unalaska.

Figure 13 shows two fallout hazard zones. The smaller area within 5 kilometers of the vent outlines the region within which humans would be at risk from ballistic impacts of large bombs during typical future eruptions from Cone A, the currently active vent in the caldera. The larger circle circumscribes the region within which significant ash fallout of several centimeters might accumulate, possibly curtailing human activities, affecting machinery and electronics, and potentially overloading flat-topped roofs.

\section{Pyroclastic Flows and Surges}

Pyroclastic flows and surges are among the most dangerous of all volcanic phenomena. Pyroclastic flows are dry mixtures of volcanic rock debris and gas as hot as $800^{\circ} \mathrm{C}$ that move rapidly down slope under the influence of gravity, like a fluid. They typically consist of coarse debris at the base of the flow, and an accompanying dilute, hot dust cloud (fig. 9). Pyroclastic flows can form when masses of ash and hot rock debris are explosively ejected and collapse onto the volcano's flanks, or when part of a growing volcanic dome collapses into rock fragments. Pyroclastic flows can attain very high velocities of around 30 to 100 meters per second, especially when they form as a consequence of laterally directed explosive eruptions or collapse from high eruption columns.

Pyroclastic surges are similar to pyroclastic flows but consist primarily of dilute mixtures of relatively fine rock fragments and ash suspended in turbulent gas. Surges may be generated by large volcanic explosions, or by the separation of elutriated ash and gas from underlying pyroclastic flows. At Okmok Volcano, explosive interactions between magma and shallow lakes within the caldera resulted in phreatomagmatic explosions at more than five different vents during the last 2,000 years, building large tuff cones and producing numerous pyroclastic surges within the caldera. On at least two occasions explosions were large enough to send surges over the caldera rim and down the flanks of the volcano to the coast, a distance of more than 10 kilometers.

Pyroclastic flows and surges are likely to accompany future eruptions in Okmok Volcano, especially if phreatomagmatic explosions occur during eruptions through lakes, glacier ice, or thick snow. Pyroclastic flows and surges constitute an especially severe hazard to humans because of their speed, mobility, and high temperatures. Pyroclastic flows and surges can travel considerable distances, burying and incinerating everything in their path, including any people or buildings they encounter. Even the slightest contact with distal ash clouds at the margin of surges or pyroclastic flows can be hazardous, as the dilute clouds can burn the skin, throat and lungs, and inhalation of the fine ash can cause asphyxiation. Also, high-velocity ash clouds and surges often occur as very powerful blasts of wind, which can blow down buildings and carry sand-sized and larger rock fragments that may cause injury by impact as well as by their intense heat (Baxter and others, 1998).

Geologic studies of the extent of prehistoric pyroclastic flow and surge deposits erupted from Okmok Volcano since the caldera-forming eruptions indicate nearly all areas within a distance of 10 kilometers from the active vent at Cone A could be affected by pyroclastic flows and surges (fig. 14). The hazard might be even greater if a new vent became active near or within one of the caldera's small lakes. Pyroclastic flows are often channeled down valleys, and low-lying areas adjacent to streams and valleys around Okmok Volcano 
should be considered particularly dangerous during explosive eruptions.

Very large and highly mobile pyroclastic flows and surges might occur at Okmok if eruptions as large as the two caldera-forming events were to recur. Such eruptions can produce pyroclastic flows that travel 30 to 40 kilometers from the volcano, potentially affecting virtually every part of the flanks of Okmok Volcano from the caldera down to the coast.

Pyroclastic flows and surges can travel across water, as has been repeatedly observed during the volcanic eruptions which began in 1997 on the island of Montserrat in the Caribbean Sea. During the large caldera-forming eruption of Krakatau Volcano in 1883, pyroclastic flows produced casualties on land in southern Sumatra after traveling more than 40 kilometers over water (Carey and others, 1996). Similarly, our geologic studies show that pyroclastic flows produced during both caldera-forming eruptions of Okmok Caldera (ca. 2,000 and 12,000 years ago) flowed down from the caldera rim to the coast on the east flank of the volcano and then traveled at least an additional 10 kilometers across Umnak Straits to the westernmost part of Unalaska Island. It is highly unlikely that a caldera-forming eruption similar to the two that happened during the last 12,000 years will recur in the near future at Okmok Volcano. However, based on the prehistoric behavior of Okmok Volcano and the historical extent of pyroclastic flows and surges during other large caldera-forming eruptions, the limit of the maximum hazard zone for pyroclastic flows and surges surrounding Okmok Volcano is set at 30 kilometers from the caldera rim (fig. 14).

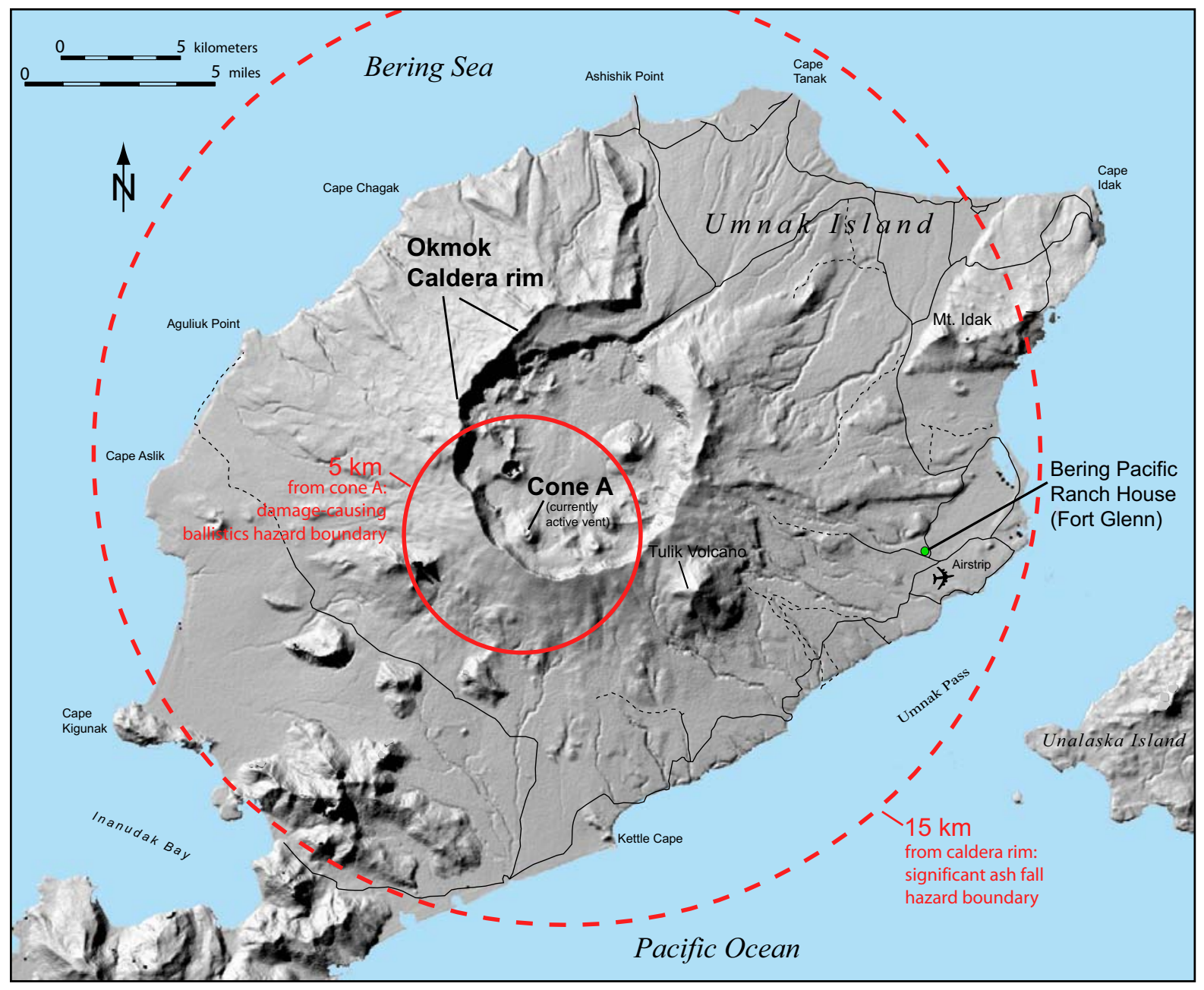

Figure 13. Ash fall and ballistic hazard areas on Umnak Island during explosive eruptions within the caldera at Okmok Volcano. Ballistics large enough to cause damage to machinery or humans are likely to be restricted to within 5 kilometers of the currently active vent, Cone A. Ash accumulations of several centimeters will likely be restricted to within 15 kilometers of the caldera rim. 


\section{Lava Flows and Domes}

Effusive eruptions of lava are common at Okmok Volcano. Non-explosive eruptions of molten rock can form local, steep-sided lava domes, or more fluid lava flows can move down slope in long, stream-like flows or form relatively thin fans of lava.

During the last 2,000 years lava flows have erupted from many different vents on the caldera floor. Since 1945, Cone A on the southwest side of the caldera has erupted several lava flows up to 8 kilometers long. While most lava eruptions have occurred within the caldera, lava flows have also been erupted at multiple sites on the flanks of the volcano during the last 12,000 years, although no such eruptions have occurred in historical time. All of these lava flows are primarily basaltic andesite to basalt in composition.

Lava flows like those erupted at Okmok Volcano usually move down slope at velocities of only a few meters to tens of meters an hour, and humans can generally escape their approach. Nonetheless, lava-flow hazards exist around active vents or in low-lying areas and valleys near vents that may be entirely buried by lava. Lengthy lava eruptions can inundate large areas, completely destroying any buildings, roads, or other structures they encounter. Lava flows can also create floods by melting snow or damming streams, as occurred in 1817 when the lava that erupted from Cone B dammed Crater Creek.

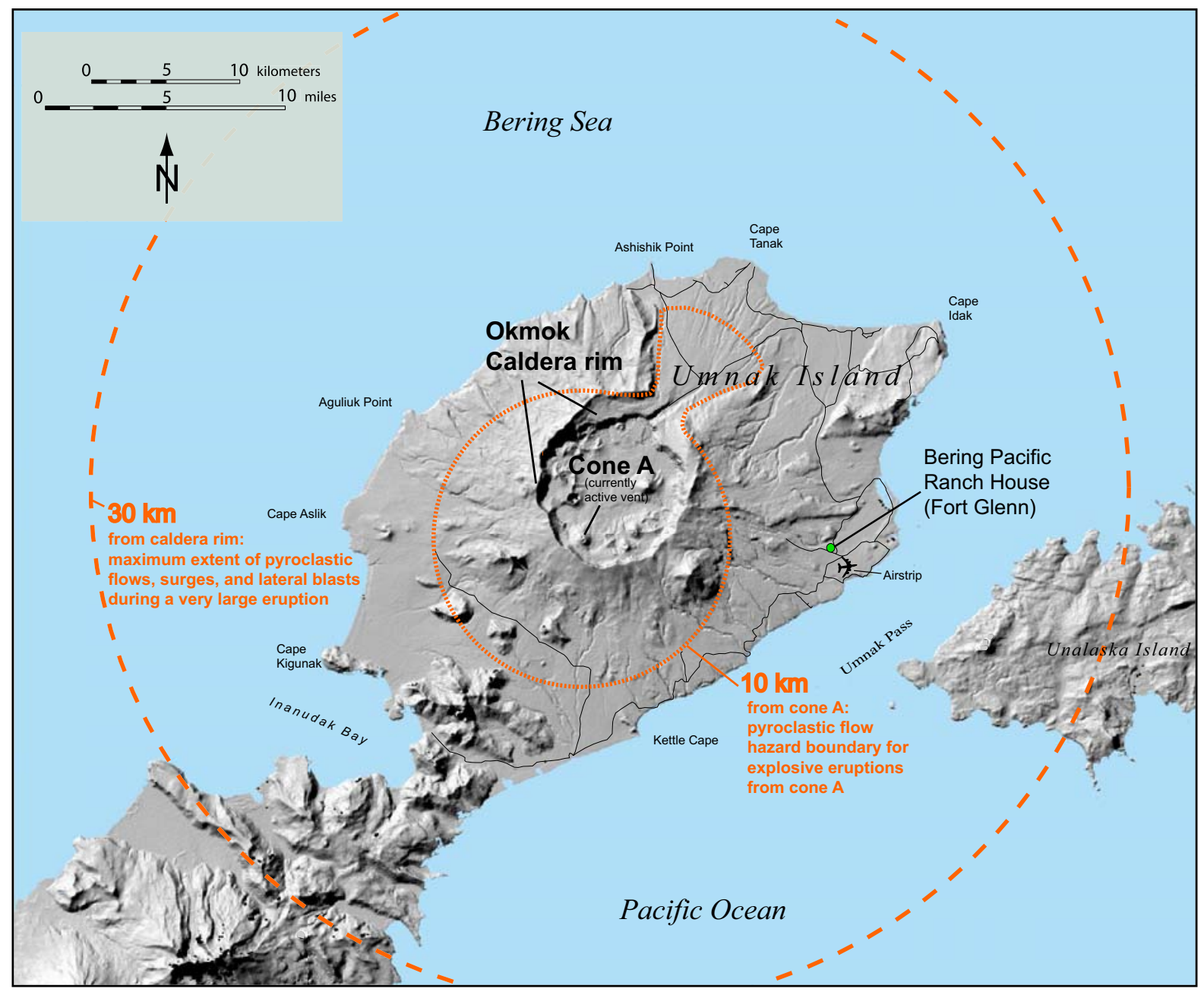

Figure 14. Areas likely to be affected by pyroclastic flows during typical small to moderate phreatomagmatic explosive eruptions are within about 10 kilometers of Cone A and the caldera. However, flows may also extend further to the northeast along the Crater Creek drainage, where the caldera wall has been breached. The maximum extent of pyroclastic flows, surges, and lateral blasts during a very large eruption similar to caldera-forming events that occurred about 2,000 years ago, extends to 30 kilometers from the caldera rim. Such large events occur very rarely at Okmok Volcano. 
Steep-sided lava domes form as a consequence of eruption of viscous lava, and are prone to collapse or even explosive eruption. Lava domes can produce ash clouds, ballistic fallout, and pyroclastic flows and surges. No large lava domes have been produced at Okmok in the last 2,000 years, but such eruptions could occur in the future.

The hazard zone for lava flows and domes encompasses the floor of the caldera, as lava eruptions are significantly more likely to occur in this area than elsewhere around the volcano. However, future lava eruptions may also occur on the upper or lower flanks of Okmok Volcano. Unless an eruption begins upslope from Fort Glenn, lava-flow eruptions at Okmok Volcano will be limited to uninhabited parts of Umnak Island, and pose little direct threat to people or property.

\section{Lahars and Floods}

Volcanic eruptions can cause floods and lahars (volcanic mudflows) by melting large amounts of glacier ice and snow, or by releasing lake water impounded in the caldera. Lahars typically consist of muddy suspensions of boulders, sand, and silt, and both floods and lahars can travel 10 to 20 kilometers or more down valley at speeds of 10 to 30 kilometers per hour.

Lahars and floods can be generated suddenly during eruptions, and may occur with little or no warning. As they travel down valley both lahars and floods can affect areas at considerable distance from the erupting vent, sometimes surprising people who believe they are at a safe distance from the eruptive activity. Lahars and floods can begin when eruptive events, such as the flow of a hot pyroclastic surge across a snowfield, rapidly melt snow and generate floods that travel rapidly down valley. The floods often rapidly transform into lahars as they erode and incorporate ash and other fragmental material on the flanks of volcanoes. Lahars can change character, by continuing to erode material or by depositing much of their sediment, especially the coarsest particles, flowing onto gentler slopes, and becoming more like water-rich flood waves. Lahars typically travel down slope along stream valleys, but are often voluminous enough to cover adjacent floodplains and low-lying areas with sediment that is centimeters to meters in thickness, and have the consistency of wet concrete, burying everything in the area.

The heavy snow that mantles Okmok Volcano in the winter (fig. 3), and a small glacier covering about 1.5 square kilometers of the north-facing wall of the caldera rim near Cone A are two potential water sources for future floods and lahars. Both of these water sources could generate floods or lahars if affected by lava flows, or by pyroclastic flows or surges, or by fallout of hot ballistics or ash. Lahars and floods initiated on the flanks of the volcano would likely follow local drainages down to the coast, while the impact of floods and lahars produced anywhere within the caldera would be restricted to the caldera itself and low-lying areas along Crater Creek.

About 300 to 400 years ago eruptions in the caldera produced a series of lahars that reached the coast west of the volcano as far as 12 kilometers from the caldera rim, burying the area in as much as 5 meters of debris. These lahars were apparently produced by eruptions within the caldera that generated pyroclastic surges and ash fallout that buried the upper west flanks of the volcano. Lahars were also found in other drainages on the flanks of the volcano, but the age of these events is not well constrained.

Floods and lahars can also be produced when existing lakes are affected by eruptive activity, or when new lakes are dammed during the course of eruptions. At Okmok Volcano, the largest lake is in the northeast part of the caldera. Eruptions through this lake, or any of the smaller lakes, or impacts to the lakes from earthquakes, pyroclastic flows or other phenomena, could potentially generate floods and lahars as occurred during the 1817 eruption (Wolfe and Begét, 2002; Grewingk, 1850).

Hazards from floods and lahars at Okmok Volcano are greatest along Crater Creek, as this drainage would be impacted by any eruptive events within the caldera that melted the caldera's winter snow pack or glacial ice, or disturbed an intra-caldera lake. Lahars and floods could also affect other areas around the volcano, although this hazard is significantly greater in winter when eruptions of hot debris would encounter the heavy winter snow pack on the upper flanks, melting the snow and causing lahars and floods that would travel down drainages toward the coast (fig. 15).

Floods and lahars produced by eruptions at Okmok Volcano during the last 300 to 400 years have reached the coast along Crater Creek as well as down drainages that originate on the west flank of the caldera rim. Drainages on the south and southwest flanks of the volcano are probably at particular risk, because recent eruptive activity has been centered at Cone A in the southwest part of the caldera. However, eruptions similar to those of the last few hundred years may affect low-lying areas along Crater Creek and on all flanks of the volcano. At the present time, all valleys heading on the flanks of Okmok Volcano are uninhabited and undeveloped, except for the area around Fort Glenn. If people are at Fort Glenn or traveling around the volcano during future eruptions, they should be very cautious in low-lying areas, as lahars and floods that are generated high on the volcano can travel down slope rapidly, overtaking any people or vehicles that may be in their path. 


\section{Rockfalls and Landslides}

Rockfall and landslide deposits occur in many places around the steep walls within the caldera, and rockfalls continue to occur with regularity. Volcanic earthquakes or explosive eruptions in the caldera would probably increase the frequency of large rockfalls from the caldera walls, and such events may occur spontaneously at any time. Rockfalls and landslides may also occur at steep cliffs outside the caldera. The collapse of steep-fronted lava flows can also generate rockfalls; these events may be accompanied by pyroclastic flows and surges if the collapse results in the sudden release of hot gas.

\section{Volcanic Gases}

Large volumes of volcanic gases are typically emitted during and immediately after eruptions, with the most common varieties being water vapor, carbon dioxide, and sulfur dioxide, along with much lesser amounts of carbon monoxide, sulfur dioxide, and hydrogen sulfide. Microscopic droplets and aerosols of sulfuric acid, hydrochloric acid, and hydrofluoric acid may form when volcanic gases encounter steam or water, and highly acidic precipitation may result from the mixing of a gasrich volcanic plume and rain or snow. Acidic volcanic aerosols can cause skin and lung irritation, and corrode

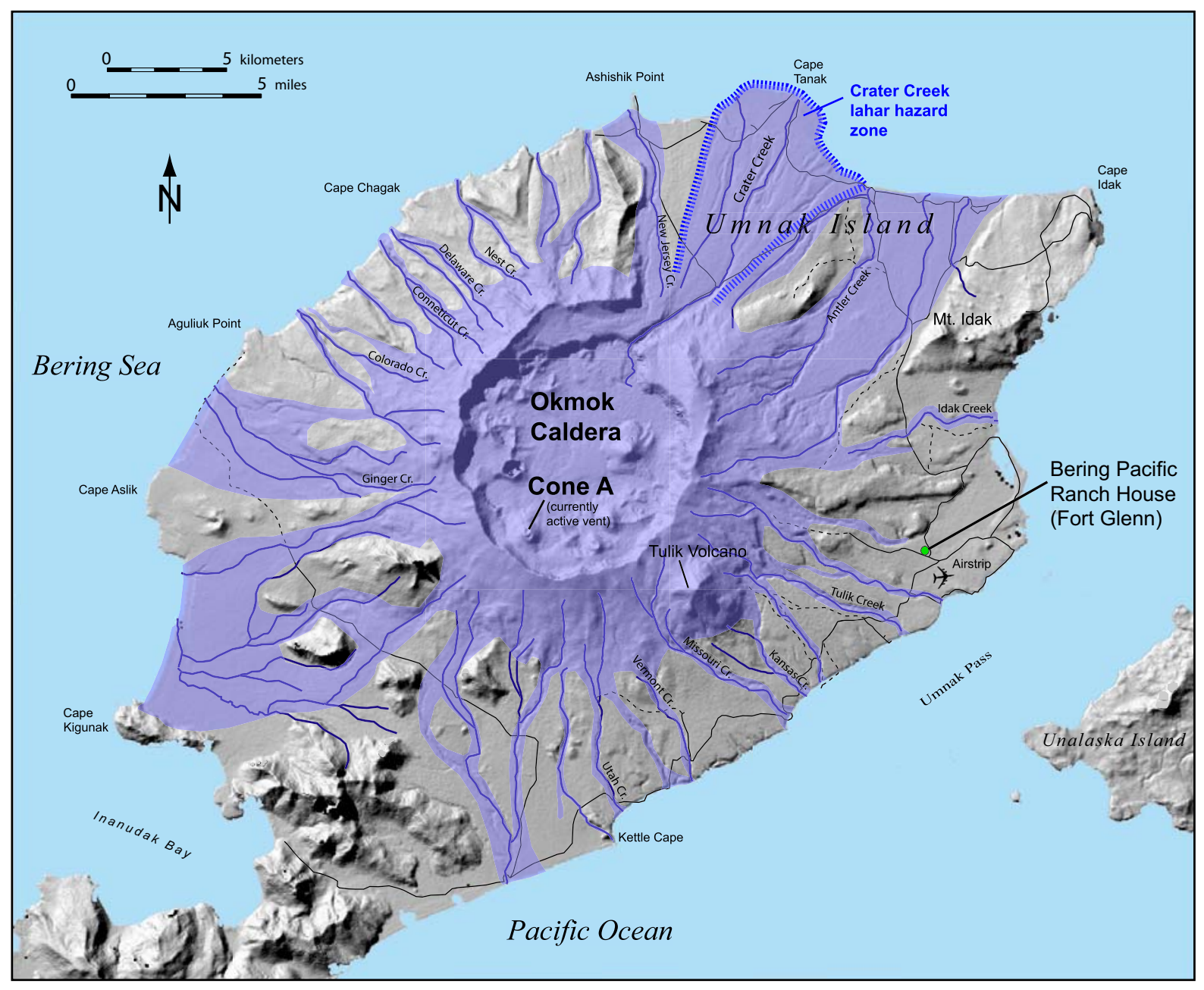

Figure 15. Floods and lahars are most likely to affect the Crater Creek region on the northeast side of Okmok Volcano, especially if ice in the caldera is melted by hot debris and lava from eruptions. Floods and lahars may also be generated high on the volcano's flanks if explosive eruptions occur in winter and generate pyroclastic flows and surges or hot ash falls that melt snow. These floods and lahars would affect mainly lowlying areas along streams that drain the volcano, but might inundate large, flat areas near the coast. 
paint, fabric, and metals. Hydrogen sulfide has a strong odor similar to rotten eggs, but other volcanic gases like carbon monoxide and carbon dioxide are colorless and odorless. Carbon dioxide is heavier than air, and may collect in low-lying areas, causing suffocation of birds, animals, and humans.

Fumaroles emitting volcanic gases are found at numerous places within the caldera at Okmok Volcano; a temperature of $110^{\circ} \mathrm{C}$ was measured at superheated steam vents on Cone $\mathrm{C}$ during geologic field work in June 2001 (Ken Papp, oral comm.). Even hotter fumaroles probably occur near the summit of Cone A where lava erupted from February to April of 1997, but these vents could not be safely approached (fig. 16). Thousands of small fumaroles were observed on the 5-kilometer-long 1997 lava flow, however these are likely to disappear as the lava continues to cool. Hot springs previously occurred near the base of Cone D and are now submerged beneath the lake that formed in 1958. Numerous bubble streams rise to the surface over a large area along the southern shore of the lake, apparently marking the sites of drowned fumaroles.

Future eruptions within Okmok Caldera or on the flanks of the volcano may emit large amounts of volcanic gas. Today, several hot springs and fumaroles occur outside the caldera at Hot Springs Cove located 20 kilometers southwest of the volcano, while others are found together with the only known geysers in Alaska at Geyser Creek, 25 kilometers to southeast (Byers, 1959).

The greatest hazards from volcanic gases and acidic aerosols during future eruptions will occur within a few hundred meters to a few kilometers of active vents, while lesser gas hazards may be associated with lava flows and pyroclastic flow deposits.

\section{VOLCANIC HAZARDS LIKELY TO BE ASSOCIATED ONLY WITH EXTREMELY LARGE ERUPTIONS OF OKMOK VOLCANO}

\section{Debris Avalanches}

Volcanic debris avalanches are giant landslides that form by collapse of the summit area or upper flanks of volcanoes. Debris avalanches can travel at speeds of 30 to 150 kilometers per hour, and may extend 10 to 20 kilometers or more from their source, burying large areas beneath many meters of coarse volcanic debris. Volcanic debris avalanches may be triggered by eruptions or large earthquakes, or may occur during

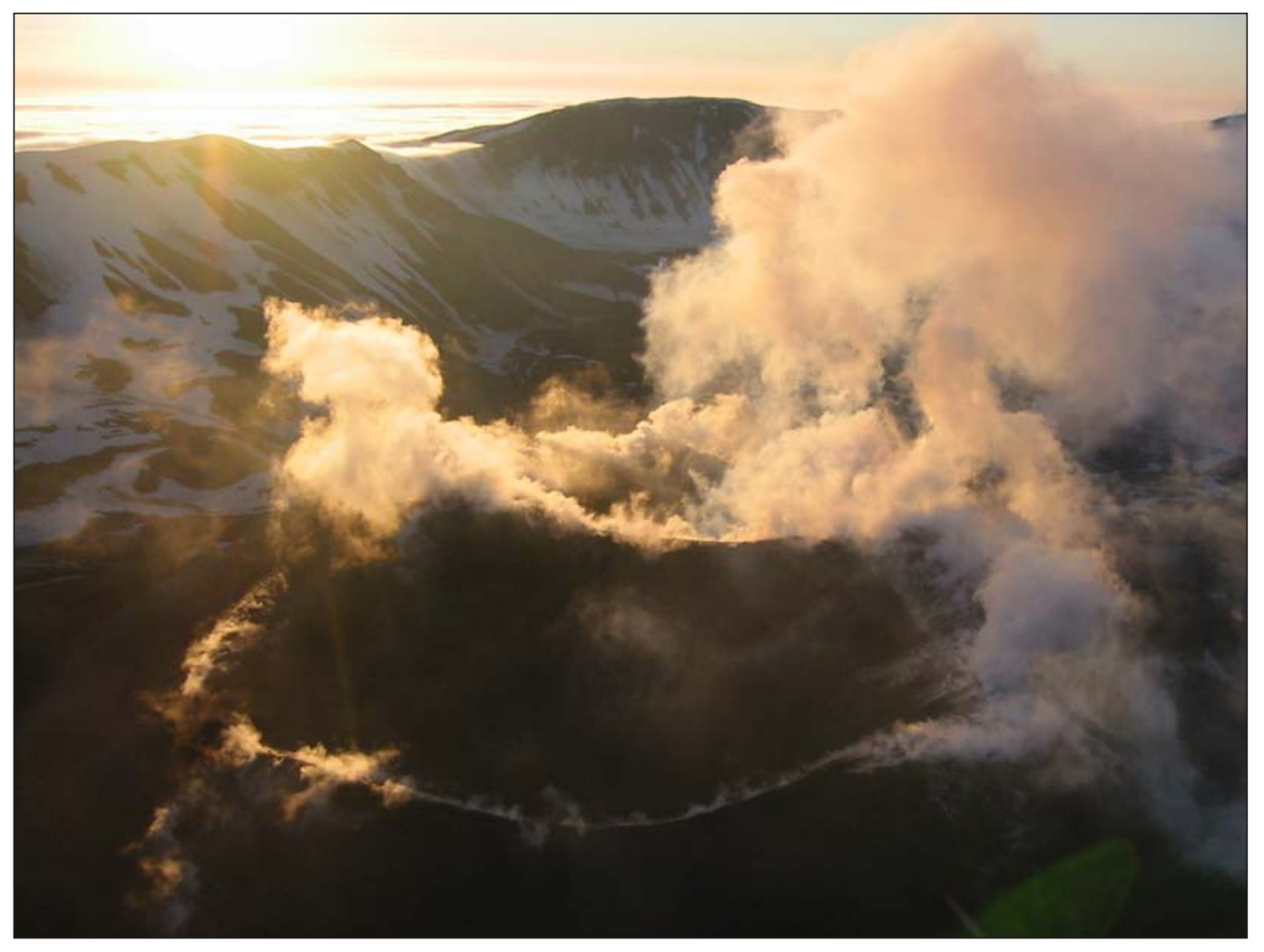

Figure 16. Large amounts of steam and gas are emitted from fumaroles on Cone A. Photo by Jeff Freymueller, University of Alaska Fairbanks Geophysical Institute, 2002. 
non-seismic and non-eruptive periods, especially where fracturing or chemical alteration has weakened the upper parts of a volcanic edifice (Begét and Kienle, 1992).

At Okmok Volcano, a debris avalanche deposit with characteristically hummocky topography overlies the 2,000-year-old pyroclastic flow deposit on the southeast flank of the volcano, and records collapse of part of the upper flanks of Tulik Volcano. This debris avalanche extends more than 6 kilometers to the modern coastline of Umnak Island, and may have traveled a short distance into the sea (fig. 17). A much larger debris avalanche deposit covers much of the northwest flank of Okmok, and records the collapse of the volcano's summit about 12,000 years ago.
Based on the low frequency of debris avalanches at Okmok, and the gentle topography characteristic of most of the volcanic edifice, it is highly unlikely that a large debris avalanche will occur in the near future. However, if such an event occurred, it would be catastrophic for anything in the path of the avalanche. The debris avalanche and landslide hazard would increase significantly if a future eruptive vent opened near Tulik Volcano, or if this area became a focus of ground deformation. Areas within the caldera are at greater risk from debris avalanches or rockfalls from the steep caldera walls than most areas on the volcano's flanks outside the caldera, although hazards also exist around areas of steeper topography on the west and north flanks of the volcano (fig. 17).

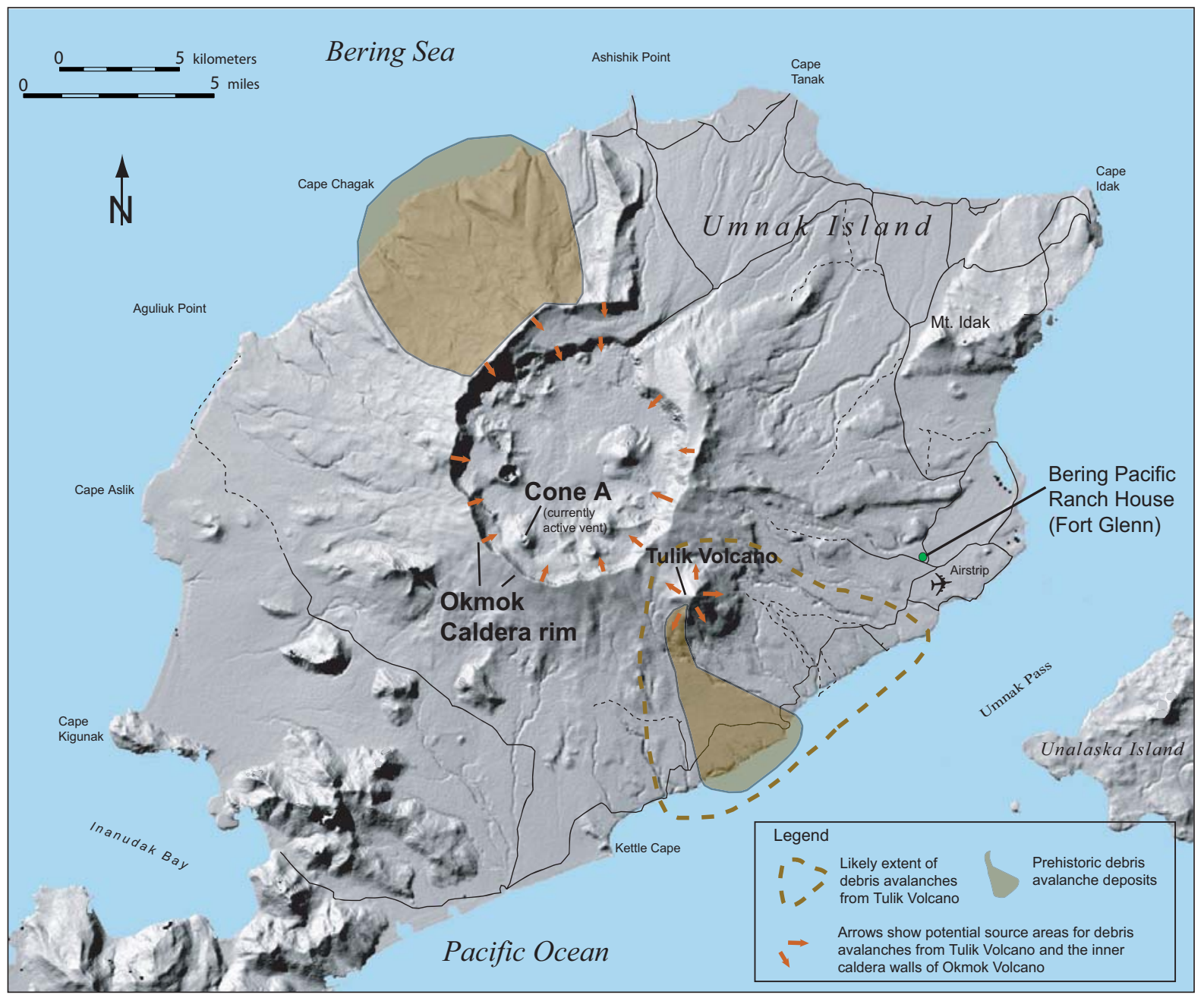

Figure 17. Debris avalanches are most likely to occur from the steep flanks of Tulik Volcano and the inner caldera walls of Okmok Volcano. The dashed line shows the likely extent of debris avalanches from Tulik Volcano. The shaded regions show areas affected by prehistoric debris avalanches. The arrows indicate potential source areas for debris avalanches from Tulik Volcano and the inner caldera walls of Okmok Volcano, but other areas of steep topography may also be hazardous. 


\section{Directed Blasts}

A directed blast is a special type of pyroclastic surge created by a laterally directed explosion caused by dome collapse or a debris avalanche that uncovers and depressurizes hot, magmatic material at a volcano (Bean, 1999; Siebert and others, 1995). No evidence of historical or prehistoric directed blasts were found at Okmok Volcano, but it is impossible to preclude the possibility that a directed blast may accompany a future eruption.

The extent of the hazard from possible future directed blasts at Okmok Volcano is based on data from the directed blast associated with the well studied 1980 eruption of Mount St. Helens Volcano in Washington state (Kieffer, 1981). This approach provides a reasonably conservative model for this hazard, and suggests that if a large directed blast were to occur at Okmok Volcano, perhaps associated with dome growth someplace on the upper flanks of the volcano, it could affect a broad area, perhaps exceeding $180^{\circ}$ in width, and might reach 25 kilometers or more from the volcano, similar to the maximum extent of pyroclastic flows associated with past caldera-forming eruptions of Okmok Volcano (fig. 14). It is possible that a directed blast that originated within the caldera might be obstructed or diverted by the caldera rim, but the blast at Mt. St. Helens traversed slopes much higher than the Okmok Volcano caldera rim. Based on the absence of evidence for past directed blasts at Okmok Volcano, it is unlikely that a directed blast will accompany an eruption there in the near future. However, if a directed blast were to occur during the course of a future eruption, there would likely be little warning during the first moments of a large explosive eruption, and a hot, energetic explosive blast would kill or destroy everything it overran.

\section{Volcanic Tsunamis}

Okmok Volcano occupies a peninsula on the northeast side of Umnak Island, and is flanked by the Bering Sea to the north and the Pacific Ocean to the south. Numerous tsunamis, some among the largest and most devastating known in historical time, have been generated during eruptions at volcanoes located near the sea (Begét, 2000). During the last 200 years about 20 percent of the known volcanic tsunamis were associated with volcanic earthquakes, while 80 percent were generated by volcanic explosions or by the displacement of seawater by large masses of volcanic debris entering the ocean (Latter, 1981). Voluminous pyroclastic flows and debris avalanches that flow into the sea at high velocity have produced the largest tsunamis, while smaller waves were associated with lahars, lava flows, surges, and volcanic earthquakes.

No tsunamis have been produced at Okmok Volcano during the relatively small eruptions of the last few hun- dred years, and tsunamis are very unlikely to be produced by eruptions of Okmok Volcano in the future. However, our geologic studies have shown that a tsunami was generated during the caldera-forming eruptions about 2,000 years ago when pyroclastic flows entered the sea on the northern, eastern, and southern flanks of the volcano. The tsunami deposits occur in several valleys on the westernmost part of Unalaska Island, and suggest waves traveled hundreds of meters inland from the current shoreline.

If an unusually large eruption, similar to the calderaforming eruptions of 2,000 and 12,000 years ago, were to occur again, and voluminous pyroclastic flows entered the sea around Okmok, it is likely that tsunami waves would be produced. It is also possible that a debris avalanche from Tulik Volcano large enough to enter the sea might produce a tsunami wave.

Based on the low frequency of such huge volcanic events at Okmok Volcano, it is very unlikely that a volcanic tsunami will be generated in the near future by an eruption. However, if such an event occurs, all coastal areas at low elevations around the easternmost parts of Umnak Island and the westernmost parts of Unalaska Island might be affected. It is possible for humans to reduce their risk by climbing to sites at higher elevation.

\section{COULD ANOTHER CALDERA- FORMING ERUPTION OCCUR AT OKMOK?}

Huge volcanic eruptions that form calderas are extremely rare, but can have enormous consequences. It is estimated that eruptions similar in magnitude to those that occurred at Okmok Volcano 12,000 and 2,000 years ago occur somewhere on our planet only about once per century to once every several hundred years (Simkin and Siebert, 1994). Okmok Volcano is unusual in having had two such eruptions spaced only 10,000 years apart. Such large eruptions can have significant impacts at distances of tens to hundreds of kilometers from the volcano. For instance, the 1883 caldera-forming eruption at Krakatau Volcano in Indonesia produced about 20 cubic kilometers of new tephra, sent pyroclastic flows and surges across water more than 40 kilometers from the volcano, and generated tsunami waves 15 to 30 meters high that inundated the shorelines of nearby islands, killing more than 36,000 people (Simkin and Fiske, 1983). A larger caldera-forming eruption at nearby Tambora Volcano in 1815 produced about 100 cubic kilometers of tephra, inducing global climate cooling that affected areas as far away as North America and Europe, and produced about 90,000 fatalities in Indonesia resulting from crop failures (Sigurdsson and Carey, 1989; Sigurdsson, 1989). 
Could Okmok Volcano once again be the site of such a huge eruption? Based on the geologic history of Okmok, such an eruption is possible, but not likely in the near future. We know from geologic studies that Okmok has undergone numerous, relatively small eruptions since the caldera-forming event 2,000 years ago. This pattern of activity shows clearly that shallow magma reservoirs reformed under Okmok Volcano soon after the eruption 2,000 years ago, and are present today. In addition to the historical record, ongoing geodetic monitoring of inflation and deflation centered on Okmok provides important information to assess recent magma storage and movement at shallow depths. Significant inflation of about 140 centimeters occurred prior to the most recent eruption in 1997, and geodetic models indicate magma storage at a depth of 2.0 to 5.0 kilometers. Since 1997, inflation has continued at varying rates, indicating additional magma moving up to the shallow storage region (Mann and Freymuller, 2003). The historical record and geodetic data suggest that at present, magma bodies at Okmok are relatively ephemeral, leading to more frequent but less explosive eruptions. This pattern of activity also allows us to say with some confidence that more such small eruptions are highly likely to occur in the future. However, studies at volcanoes around the world have shown that after a caldera-forming eruption it takes a significant period of time for enough magma to be generated for another giant eruption to occur (Simkin and Siebert, 1994). At Okmok itself, the 10,000 years that passed between its first caldera-forming event 12,000 years ago and the more recent event 2,000 years ago provide evidence of this principle.

There is a link between the composition of magmas erupted at Okmok and the relative size of the eruption. The two violent caldera-forming eruptions both were distinct with the presence of rhyodacitic magma (70 wt. \% SiO2), yet the bulk of those eruptions produced basaltic-andesite material (54-56 wt. \% SiO2). The more frequent, smaller, and less explosive eruptions also typically involve basaltic-andesite magma, yet lack the distinctive presence of more silicic magma erupting early in the sequence. In this regard, eruption of silicic magma at Okmok may be an indication that a large, catastrophic eruption is imminent.

\section{ERUPTION FREQUENCY AND VOLCANIC RISK AT OKMOK VOLCANO}

The historical record and our geologic studies of prehistoric deposits demonstrate that Okmok Volcano erupts frequently. The 16 eruptions documented in the last 200 years suggest eruptions have occurred, on average, about every 12 years. The eruption frequency during the half century since World War II is even higher, with eruptions occurring, on average, about every 7 years. The prehistoric pattern of eruptions, interpreted from the recognition of numerous tephra deposits preserved on the flanks of Okmok Volcano since the caldera-forming eruption 2,000 years ago, implies a recurrence interval of approximately 75 years. These recurrence interval calculations probably underestimate the actual frequency of eruptions at Okmok Volcano, because it is highly likely that some eruptions during historical time went unobserved, and that some prehistoric eruptions did not leave recognizable deposits.

The frequency data provide clues to the size of likely future eruptions. The prehistoric record contains evidence only of explosive eruptions large enough to deposit a centimeter or more of tephra at distances of 5 kilometers or more from the vent, while the historical record of Okmok's activity includes both explosive and nonexplosive eruptions, and eruptions of large and small volumes of material. The 7- to 12-year average duration between eruptive events that has characterized the last 200 years should therefore be interpreted as a estimate of overall eruption frequency, while the 75-year recurrence interval determined from the prehistoric record can be interpreted as an estimate of the frequency of only those explosive eruptions large enough to leave significant tephra deposits on the flanks of the volcano. The 1817 and 1958 eruptions were the only historical events as large as those that are preserved as part of the prehistoric record.

The historical and prehistoric records of activity at Okmok Volcano suggest that eruptions are highly likely to occur there during the 21st century. The primary volcanic hazard during such future eruptions will be from volcanic ash clouds, which will deposit ash locally on eastern Umnak Island, and may drift over other Aleutian Islands, parts of the North Pacific Ocean, and mainland Alaska and North America. Such ash clouds may interfere with operations of the International Airport at Dutch Harbor, as well as the more than 200 commercial and passenger jet flights between Asia, Europe, and North America that cross the North Pacific each day. During large eruptions similar to the 1817 event, aircraft operations around Okmok Volcano and areas of the North Pacific through which volcanic ash is dispersed may be affected for extended periods of time. Ash fallout on Unalaska, the nearest populated city, could be a few millimeters to a few centimeters thick if prevailing winds carried ash clouds eastward. Such ash falls could interfere with the operation of engines and generators, and would affect commercial and civic activities. On eastern Umnak Island itself, the caldera and some areas on the flanks of Okmok Volcano are likely 
to be affected by floods, lahars, and small surges and pyroclastic flows during future eruptions. The exact areas outside the caldera that might be affected are impossible to predict, but the low-lying areas all along Crater Creek are probably significantly more at risk than other areas around the volcano.

It is much more difficult to evaluate the frequency and risk from significantly larger eruptions. An eruption as large as the caldera-forming event ca. 2,000 years ago could have very serious consequences, but there is only a very small likelihood of such an eruption in the near future. The greatest hazard from such a large, rare eruption would be the generation of highly mobile pyroclastic flows and surges with the potential to travel 30 kilometers or more from the volcano. Such flows would destroy everything on eastern Umnak Island, would probably travel some distance across the sea, and might also produce tsunamis. Such explosive eruptions would also produce much more widespread and longer-lived ash clouds over the North Pacific air traffic corridors than any previously seen, and might produce ash falls near Dutch Harbor of 10 to 20 centimeters or more in thickness.

\section{PRECURSORY ACTIVITY, VOLCANO MONITORING, AND HAZARD MITIGATION}

The Alaska Volcano Observatory (AVO), a joint facility of the U.S. Geological Survey, the University of Alaska Fairbanks Geophysical Institute, and the State of Alaska Division of Geological \& Geophysical Surveys, was established in 1988 to evaluate volcano hazards in Alaska and to issue warnings of imminent volcanic eruptions (Brantley and others, 2004; Eichelberger and others, 1995). Scientists from AVO have installed a network of instruments at Okmok Volcano to monitor earthquakes and ground deformation that will almost certainly precede any future volcanic eruptions. In most cases volcanic eruptions are preceded by hours to months of earthquakes, providing warning of future eruptions. Any significant eruption at Okmok would likely be preceded by migration of magma and other fluids toward the ground surface in the caldera, producing many small and moderately large earthquakes. Some of the larger earthquakes would probably be felt by people living in the Fort Glenn area on the flanks of the volcano, and perhaps even by people at Unalaska.

Since 2002, the AVO has been monitoring Okmok Volcano with a real-time seismic and geodetic network (fig. 18) that can detect increases in frequency and magnitude of seismic activity (earthquakes) and detects ground deformation that typically precedes eruptions. Radio-telemetry connects the seismometers and ground deformation stations with a repeater near Fort Glenn that transmits the data to a receiver site in Dutch Harbor, where the signal is sent along telephone lines to AVO laboratories in Fairbanks and Anchorage. While the seismic network was not in place during prior eruptions of Okmok Volcano, the AVO staff is very experienced in recognizing precursory seismic activity and will likely be able to provide warning of future eruptions of the volcano.

Other monitoring techniques are also being utilized to better predict the timing and magnitude of a potential eruption. Satellite observations of the volcano are made daily to detect any thermal anomaly and to identify and track any ash erupted into the atmosphere. Intermittent ground-based measurements are also made of changes in temperatures of fumaroles and lava cones. Other techniques used on occasion include remote observation using highly sensitive video cameras equipped with infrared sensors, time-lapse cameras, and geodetic surveying using laser theodolites and global positioning satellites. Several different types of geologic studies are also being done, all of which have been successfully applied by AVO scientists to help understand the nature of volcanic hazard at Okmok.

AVO distributes by fax and e-mail a weekly volcanic activity report describing the status of 27 monitored volcanoes in Alaska, including Okmok Volcano. During periods of precursory activity or eruption, the AVO releases daily status reports and more frequent updates as conditions at the volcano change. Copies of the report are sent directly to the Federal Aviation Administration, the National Weather Service, local U.S. military bases and airports, the Governor's office of the State of Alaska, the Alaska Department of Emergency Services, airports and air carriers, and municipal and other civil authorities in the areas around the volcano. Updates are also sent to television and radio stations, newspapers, news wire services and others for dissemination to the general public. To make this information as widely available as possible in a timely fashion, it is also posted on the AVO web page (http://www.avo. alaska.edu/).

AVO uses a color code system to summarize the status of volcanoes in Alaska. The color code is used to quickly and simply summarize the level of concern (fig. 19). During a volcanic crisis the AVO staff can use the level-of-concern color code to quickly communicate changes in volcanic activity to government agencies, who can then make decisions about governmental response to eruptions. Visitors to Okmok Volcano should check the latest level-of-concern color code released by the AVO before making an extended visit to the volcano.

If signs of volcanic unrest and magma migration were detected at Okmok Volcano, AVO would begin 
intensive monitoring. In some cases, AVO would institute 24-hour-a-day staffing to ensure continuous observation. The AVO would frequently communicate information about the status of Okmok Volcano together with their interpretations of its behavior to local, state, and federal officials and the media through previously established communication channels. If AVO determined that an eruption was imminent, a warning would be released immediately by fax, telephone calls, e-mail, and a posting on the AVO website, together with a discussion of likely impacts of the eruption.

Once an eruption began, an announcement would be made to all critical government, military, and civil defense officials. Depending on the size and impact of the volcanic activity, AVO would combine satellite observations, seismic monitoring, geodetic changes, airplane overflights, on-site observation, and reports by pilots and other observers to interpret the behavior of the volcano and rapidly detect any changes in the course of the eruption. AVO would cooperate with the National Weather Service and local officials to warn areas which might be affected by ash falls or other volcanic phenomena.

AVO would also notify government agencies and the media when the eruption decreases in intensity or stops, and AVO would continue to monitor the volcano for any sign of a resumption of eruption activity. Finally, AVO will undertake scientific studies of the volcanic deposits and the instrumental record of the eruption and its precursors to better understand the behavior of Okmok Volcano, and to improve the overall knowledge of volcanic hazards and volcano monitoring.

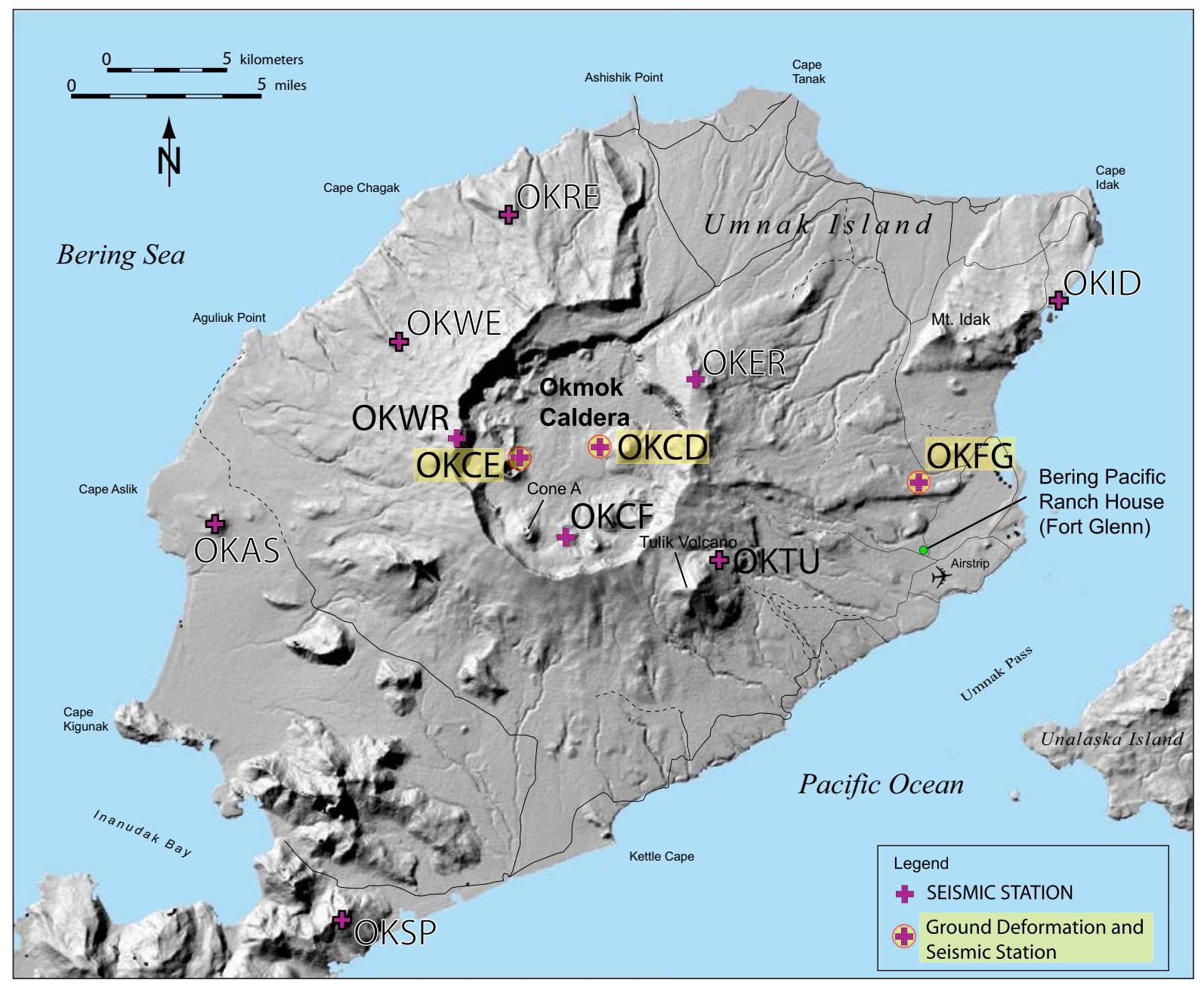

Figure 18. Location of seismic and geodetic monitoring stations around Okmok Volcano. This network is designed to detect small earthquakes beneath the volcano and ground deformation at the surface that may signal the onset of a volcanic eruption. 


\section{LEVEL OF CONCERN COLOR CODE}

\section{GREEN: Volcano is in its normal "dormant" state.}

YELLOW: Seismic activity is elevated. Potential for eruptive activity is increased. A plume of gas and steam may rise several thousand feet above the volcano which may contain minor amounts of ash.

ORANGE:

Small ash eruption expected or confirmed.

Plume(s) not likely to rise above 7,620 meters $(25,000$ feet)

above sea level. Seismic disturbance recorded on local seismic

stations, but not recorded at more distant locations.

RED:

Large ash eruptions expected or confirmed.

Plume(s) likely to rise above 7,620 meters $(25,000$ feet) above

sea level. Strong seismic signal recorded on all local and

commonly on more distant stations.

Figure 19. Alaska Volcano Observatory (AVO) level-of-concern color code. Color codes are updated based on changing conditions, and are used to quickly indicate the status of Okmok Volcano and other Alaska volcanoes. The current level-of-concern color code, written explanations, and status reports are distributed to government agencies, the media, airlines, and the public, and are posted on the AVO website (www.avo.alaska.edu).

\section{WHAT CAN BE DONE TO PREPARE FOR AN ERUPTION AT OKMOK VOLCANO?}

Okmok will erupt again. Individual citizens and concerned government officials can help mitigate the impacts of future eruptions by being aware of the potential hazards and by taking steps to prepare for them. Although the area in the immediate vicinity of Okmok Volcano is very sparsely populated and is not experiencing rapid population growth or development, volcanic hazards should be considered in future plans for land use and development of areas that might be affected by volcanic phenomena during an eruption.

According to census data maintained by the State of Alaska, about 4,200 people live within 125 kilometers of Okmok Volcano. This number can increase significantly during fishing season, when many fishing boats travel to Unalaska and fish along the Aleutian Islands and in the Bering Sea. On eastern Umnak Island as many as several dozen people may be present in the Fort Glenn area during the summer. Property owners, native tribal authorities, government officials, and land managers should be aware of the potential hazards that may accompany future eruptions of Okmok Volcano, and develop emergency response plans.

Residents of Fort Glenn and other nearby communities, visitors to the area, and fishermen who sail close by Okmok Volcano should also be aware of the hazards that may accompany eruptions of this volcano. The planning for volcanic emergencies is similar to that for other natural disasters such as flooding, earthquakes, and extreme weather. Interruptions in electrical service and surface transport and air travel may occur. People (especially those with respiratory problems) and children may be restricted from outdoor activities. If the volcanic emergency becomes very severe, evacuation and closure of some areas may be necessary. It is desirable to have emergency supplies of food, water, and fuel, and to have a plan to deal with disruption of normal services and communication.

This report is designed to provide an outline of the potential hazards associated with possible future eruptions of Okmok Volcano, and is suitable for use by both 
government agencies and private individuals. Scientists of the AVO will be available for detailed discussions during any future crises that may occur at Okmok Volcano.

\section{ACKNOWLEDGMENTS}

The authors gratefully acknowledge the input of our reviewers, Dr. Charles Bacon and Kristi Wallace of the U.S. Geological Survey. Funding for this work was provided by the U.S. Geological Survey through participating agencies of the Alaska Volcano Observatory.

\section{REFERENCES}

Baxter, P.J., Neri, A., and Todesco, Micol, 1998, Physical modelling and human survival in pyroclastic flows: Natural Hazards, v. 17, p. 163-176.

Bean, K.W., 1999, The Holocene eruptive history and stratigraphy of Makushin Volcano, Unalaska Island, Alaska. University of Alaska Fairbanks unpublished M.S. thesis, 130 p.

Begét, J.E., 2000, Volcanic tsunamis, in Sigurdsson, H., Houghton, B., McNutt, S., Rymer, H., and Stix, J., eds., Encyclopedia of Volcanoes: San Diego, CA, Academic Press, p. 1005-1014, ISBN 0-12643140-X.

Begét, J.E., and Larsen, J.F. 2001, Links between prehistoric high-latitude volcanic eruptions, aerosol events in the GISP2 ice core, Roman records, and Holocene climate change: Challenges of a Changing Earth, International Geosphere-Biosphere Program, Amsterdam, NL, July 2001, Abstract Volume, p. 185.

Begét, J.E., and Kienle, Jürgen, 1992, Cyclic formation of debris avalanches at Mount St. Augustine volcano: Nature, v. 356, p. 701-704.

Black, R.F., 1974, Late-Quaternary sea level changes, Umnak Island, Aleutians-Their effects on ancient Aleuts and their causes: Quaternary Research, v. 4, p. 264-281.

Blong, R.J., 1984, Volcanic Hazards: a sourcebook on the effects of eruptions: Sydney, Australia, Academic Press, 424 p.

Brantley, S.R., ed., 1990, The eruption of Redoubt Volcano, Alaska, December 14, 1989-August 31, 1990: U.S. Geological Survey Circular 1061, 33 p.

Brantley, S.R., McGimsey, R.G., and Neal, C.A., 2004, The Alaska Volcano Observatory-Expanded monitoring of volcanoes yields results: U.S. Geological Survey Fact Sheet FS 2004-3084, 2 p.

Byers, F.M., Jr., Hopkins, D.M., Wier, K.L., and Fisher, B., 1947, Part 3: Volcano investigations on Umnak Island, 1946: U.S. Geological Survey, Alaskan Volcano Investigations Report No. 2: Progress of Investigations in 1946, p. 19-53.
Byers, F.M., 1959, Geology of Umnak and Bogoslof Islands, Aleutian Islands, Alaska: U. S. Geological Survey Bulletin 1028-L, p. 167-369.

Carey, S., Sigurdsson, H., Mandeville, C., and Bronto, S., 1996, Pyroclastic flows and surges over water: an example from the 1883 Krakatau eruption: Bulletin of Volcanology, v. 57, p. 493-511.

Casadevall, T.J., ed., 1994, Volcanic ash and aviation safety: Proceedings of the first international symposium on volcanic ash and aviation safety: U.S. Geological Survey Bulletin 2047, 450 p.

Coats, R.R., 1950, Volcanic activity in the Aleutian arc: U.S. Geological Survey Bulletin 974-B, p. 35-47.

Dunn, R., 1908, On the chase for volcanoes: Outing Magazine, v. 51, p. 540-50.

Eichelberger, J.C., Keith, T.E.C., Miller, T.P., and Nye, C.J., 1995, The 1992 eruptions of Crater Peak Vent, Mt. Spurr Volcano, Alaska: U.S. Geological Survey Bulletin 2139, p. 1-18.

Grewingk, Constantin, 1850, Beitrag zur Kentniss der orographischen und geognostichen Beschaffenheit der Nordwest Kueste Amerikas, mit den aliegenden Inseln. Russ. K. min. Gesell. Verh., St. Petersburg, 1848-49, p. 128-133, p. 206.

Grey, D.M., 2003, Post-caldera eruptions at Okmok Volcano, Umnak Island, Alaska, with emphasis on recent eruptions from Cone A: University of Alaska Fairbanks unpublished M.S. thesis, 135 p.

Hantke, Gustav, 1951, Uebersicht ueber die vulkanische Taetigkeit, 1941-1947, Bulletin of Volcanology, v. 11, p. 161-208.

Holmes, C., 1994, Good-Bye, Boise...Hello, Alaska: Greendale, Wisconsin, Country Books, 154 p.

Jaggar, T.A., 1931, Difficulties of Alaskan earthquake study: The Volcano Letter, no. 337, p. 1-3.

Keller, Al, 1991, Okmok caldera, in Rennick, Penny, ed., Alaska’s volcanoes: Alaska Geographic, v. 18, no. 2, p. 60-68.

Kieffer, S.W., 1981, Fluid Dynamics of the May 18 blast at Mount St. Helens, in Lipman, P.W., and Mullineaux, D.R., eds., The 1980 eruptions of Mount St. Helens, Washington: U.S. Geological Survey Professional Paper 1250, p. 379-400.

Klimasauskas, Ed, Bacon, Charles, Alexander, Jim, 2002, Mount Mazama and Crater Lake: Growth and destruction of a Cascade volcano: U.S. Geological Survey Fact Sheet 092-02, 4 p.

Langsdorff, G.H. von, 1812, Bemerkungen auf einer Reise um die Welt in den Jahren 1803 bis 1807 (Remarks and Observations on a Voyage Around the World from 1803 to 1807), vol. 2, Frankfurt am Main: translated by Victoria Joan Moessner, 1993, Limestone Press, Kingston, Ontario, Canada, 145 p.

Latter, J.H., 1981, Tsunamis of volcanic origin: Bulletin of Volcanology, v. 44, p. 467-490. 
Luetke, F.P., 1836, Voyage Autour du Monde, execute par ordre de Sa Majesté l'empereur Nicolas 1er, sur la corvette le Séniavine, dans les années 18261829, vol. 3, Didot Frères, Paris.

Mann, D., and Freymueller, J., 2003, Volcanic and tectonic deformation of Unimak Island in the Aleutian Arc, Alaska: Journal of Geophysical Research, v. 108, p. 1-12.

McGimsey, R.G., and Wallace, K.L, 1999, 1997 Volcanic Activity in Alaska and Kamchatka: Summary of Events and Response of the Alaska Volcano Observatory: U.S. Geological Survey Open-File Report 99-448, p. 18-23.

Miller, T.P., McGimsey, R.G., Richter, D.H., Riehle, J.R., Nye, C.J., Yount, M.E., and Dumoulin, J.A., 1998, Catalog of the historically active volcanoes of Alaska: U.S. Geological Survey Open-File Report 98-582, 104 p.

Myers, B.M., Brantley, S.R., Stauffer, P., and Hendley, J.W., II, 1997, What are volcano hazards?: U.S. Geological Survey Fact Sheet 002-97, 2 p.

Nye, C.J., 1983, Petrology and geochemistry of Okmok and Wrangell Volcanoes, Alaska: University of California, Santa Cruz, Ph.D. dissertation, 208 p.

Nye, C.J.,1990, Okmok Caldera: eastern Aleutian Islands, in Wood, C.A., and Kienle, Jürgen, eds., Volcanoes of North America: Cambridge University Press, p. 41-43.

Nye, C.J., and Reid, M.R., 1985, Geochemistry of primary and least fractionated lavas from Okmok Volcano, central Aleutians: Implications for arc magmagenesis: Journal of Geophysical Research, v. 91, no. B10, p. 10,271-10,287.

Robinson, C.D., 1948, Exploring Aleutian Volcanoes: National Geographic Magazine, v. 94, p. 509-528.

Scott, W.E., 1989, Volcanic and related hazards, in R.E. Tilling, ed., Volcanic Hazards: Washington, D.C., American Geophysical Institute, p. 9-23.

Siebert, Lee, Begét, J.E., and Glicken, Harry, 1995, The 1883 and late-prehistoric eruptions of Augustine volcano, Alaska, in Yoshiaki, Ida, and Voight, Barry, eds., Models of magmatic processes and volcanic eruptions: Journal of Volcanology and Geothermal Research, v. 66, no. 1-4, p. 367-395.

Sigurdsson, H., 1989, Evidence of volcanic loading of the atmosphere and climatic response: Palaegeogeography, Palaeoclimatology, Palaeoecology, v. 89, p. 277-289.

Sigurdsson, H., and Carey, S.N., 1989, Plinian and coignimbrite tephra fall from the 1815 eruption of Tambora Volcano: Bulletin of Volcanology, v. 51, p. 243-270.
Simkin, Tom, and Fiske, Robert S., 1983, Krakatau 1883: The volcanic eruption and its effects: Washington, D.C., Smithsonian Institution Press, 464 p.

Simkin, Tom, and Siebert, Lee, 1994, Volcanoes of the World: Tucson, Arizona, Geoscience Press, 349 p.

Swanson, S.W., and Begét, J.E., 1994, Melting properties of volcanic ash, in Casadevall, T.J., ed., Volcanic ash and aviation safety: Proceedings of the First International Symposium on Volcanic Ash and Aviation Safety: U.S. Geological Survey Bulletin 2047, p. 87-92.

Veniaminov, I., 1840, Zapiski ob ostrovkh Unalashkinskago otdela (Notes on the islands of the Unalashka District), St. Petersburg, translated by L.T. Black and R.H. Geoghegan, 1984, R.A. Pierce (ed.): Kingston, Ontario, Canada, Limestone Press, 513 p.

Waythomas, C.F., and Waitt, R.B., Jr., 1998, Preliminary volcano-hazard assessment for Augustine Volcano, Alaska: U. S. Geological Survey OpenFile Report 98-106, 39 p.

Waythomas, C.F., Dorava, J.M., Miller, T.P., Neal, Christina A., and McGimsey, R.G., 1998, Preliminary volcano-hazard assessment for Redoubt Volcano, Alaska: U. S. Geological Survey Open-File Report 97-857, $40 \mathrm{p}$.

Wilcox, R.E., 1959, Some effects of recent volcanic ash falls with special reference to Alaska: U. S. Geological Survey Bulletin 1028-N, p. 409-476.

Wolfe, B.A., and Begét, J.E., 2002, Destruction of an Aleut village by a catastrophic flood release from Okmok Caldera, Umnak Island, Alaska: Geological Society of America Abstracts with Programs, v. 34, no. 6., p. 126.

Wolfe, B.A., 2001, Paleohydrology of a catastrophic flood release from Okmok caldera and post-flood eruption history at Okmok Volcano, Umnak Island, Alaska: University of Alaska Fairbanks unpublished M.S. thesis, $100 \mathrm{p}$.

Wong, L.J., 2004, Physical volcanology of a sub-plinian and phreatomagmatic eruption at Okmok Volcano, Alaska: Implications for explosive mafic volcanism: University of Alaska Fairbanks unpublished M.S. thesis, 117 p.

\section{GLOSSARY OF SELECTED TERMS}

Andesite. A fine-grained volcanic rock made up of feldspars and ferromagnesian minerals; typically has a SiO2 content of 54 to about 62 percent.

Ash. Fine fragments (less than 2 millimeters across) of lava or rock formed in an explosive volcanic eruption. 
Bomb. Fragment of molten or semi-molten rock, greater than 64 millimeters in diameter, which is blown out during an eruption. Because of their plastic condition, bombs are often modified in shape during their flight or upon impact.

Cinder cone. A conical hill formed by the accumulation of cinders and other pyroclastic debris around a volcanic vent.

Cinders. Glassy, vesicular, volcanic fragments, ranging in size from 4 to 32 millimeters, that fall to the ground in a solid condition.

Debris avalanche. Rapidly moving, dry flows of disaggregated rock debris, sand, and silt. Volcanic debris avalanches often form by some type of structural collapse of the volcano, usually the steep front of a cooled lava dome or other parts of the upper edifice. A large part of the volcano may become unstable, break away from the volcanic massif, and become an avalanche. Debris avalanches, which may be triggered by an eruption or earthquake, move at velocities ranging from a few tens of meters per second to more than 100 meters per second and behave like complex granular flows or slide flows. They may be quite voluminous (greater than 10 cubic kilometers) and run out considerable distances (up to 85 kilometers) from their source. The resulting debris avalanche deposit usually exhibits hummocky surface morphology.

Directed blast. Large-scale volcanic explosions caused by a major landslide or slope failure that results in a rapid drop in the pressure of the intruding magma near the surface of the volcanic edifice. The 1980 eruption of Mount St. Helens was triggered by a massive slope failure and the subsequent laterally directed blast affected a 180-degree sector north of the volcano and extended for several tens of kilometers outward (Kieffer, 1981). A directed blast typically travels away from the volcano at a low angle and may not be deflected by ridges or other topographic barriers. Rock debris propelled by a directed blast moves much faster than typical landslides and rockfalls. For example, at Mt. St. Helens, the initial velocity of the directed blast cloud was about 600 kilometers per hour, decreasing to about 100 kilometers per hour at a distance 25 kilometers from the volcano (Kieffer, 1981).

Edifice. The upper part of the volcanic cone, including the vent and summit areas.

Effusive eruption. An eruption dominated by the outpouring of lava onto the ground is often referred to as an effusive eruption (as opposed to the violent fragmentation of magma by explosive eruptions).
Eruption cloud. Cloud of gas, ash, and other fragments that forms during an explosive volcanic eruption and travels long distances with prevailing winds.

Eruption column. The vertical part of the eruption cloud that rises above a volcanic vent.

Fallout. A general term for debris that falls to the earth from an eruption cloud.

Fumarole. Small, vent-like crack or opening with escaping gas and steam.

Holocene epoch. The period of earth history from 10,000 years before present to the present.

Lahar. An Indonesian term for a debris flow containing angular clasts of volcanic material. For the purposes of this report, a lahar is any type of sediment-water mixture originating on or from the volcano. Most lahars move rapidly down the slopes of a volcano as channelized flows, delivering large amounts of sediment to the rivers and streams that drain the volcano. The flow velocity of some lahars may be as high as 20 to 40 meters per second (Blong, 1984), and sediment concentrations of greater than 75 percent are not uncommon. Large-volume lahars can travel great distances if they have an appreciable clay content ( $>3$ to 5 percent), remain confined to a stream channel, and do not significantly gain sediment while losing water. Thus, they may affect areas as far as hundreds of kilometers downstream from a volcano.

Lapilli. Ejected rock or pumice fragments between 2 and 64 millimeters in diameter.

Lava. Molten rock that reaches the earth's surface.

Lava dome. A steep-sided mass of viscous and often blocky lava extruded from a vent; typically has a rounded top and roughly circular outline.

Maar. A low-relief, broad volcanic crater formed by a shallow, phreatomagmatic, explosive eruption. It may contain a lake.

Magma. Molten rock beneath the earth's surface.

Petrology. The geologic study of the origin, occurrence, structure, and history of rocks.

Phreatomagmatic eruption. An explosive volcanic eruption that results from the interaction of surface or subsurface water and magma.

Pleistocene epoch. The period of earth history between 1.8 million and 10,000 years before present.

Pumice. Highly vesicular volcanic ejecta; because of its extremely low density, it often floats on water.

Pyroclastic. General term applied to volcanic products or processes that involve explosive ejection and fragmentation of erupting material.

Pyroclastic flow. A dense, hot, chaotic avalanche of rock fragments, gas, and ash that travels rapidly away 
from an explosive eruption column, often down the flanks of the volcano (synonymous with 'ash flow'). Pyroclastic flows move at speeds ranging from 10 to several hundred meters per second and are typically at temperatures between $300^{\circ} \mathrm{C}$ and $800^{\circ} \mathrm{C}$ (Blong, 1984).

Pyroclastic flows form either by collapse of the eruption column or by failure of the front of a cooling lava dome. Once these flows are initiated, they may travel distances of several kilometers and easily override topographic obstacles in the flow path. A person could not outrun an advancing pyroclastic flow.

Pyroclastic surge. A low-density, turbulent flow of finegrained volcanic rock debris and hot gas. Pyroclastic surges differ from pyroclastic flows in that they are less dense and tend to travel as a low, ground-hugging — but highly mobile — cloud that can surmount topographic barriers. Surges often affect areas beyond the limits of pyroclastic flows.

Scoria. Coarsely vesicular pyroclastic rock that is heavier and darker than pumice.

Stratovolcano (also called a 'stratocone' or 'composite cone'). A steep-sided volcano, usually conical in shape, built of lava flows and fragmental deposits from explosive eruptions.

Strombolian. An eruption style characterized by pulselike explosive bursts and low-level emission of ash and pyroclastic debris. Usually each burst lasts for only a few seconds, and sustained eruption columns generally do not develop.

Sulfurous. Sulfur-bearing or rich in sulfur compounds.
Surge. See Pyroclastic surge.

Tephra. Any type of rock fragment that is forcibly ejected from the volcano during an eruption. Tephra may be fine-grained dust or 'ash' $(0.0625$ to 2-millimeter-diameter, silt to sand-sized), coarser 'lapilli' (2 to 64-millimeter-diameter, sand to pebblesized), or large blocks or bombs (>64 millimeter, cobble to boulder-sized). When tephra is airborne, the coarsest fraction will be deposited close to the volcano, but the fine fraction may be transported long distances and can stay suspended in the atmosphere for many months. Tephra particles are typically sharp, angular, and abrasive, and are composed of volcanic glass, mineral, and rock fragments.

Tsunami. Tsunami is a Japanese word meaning "harbor wave." A tsunami is a wave or series of waves that are generated in a body of water by a sudden disturbance that displaces water. They are typically caused by earthquakes and landslides in coastal regions. Volcanic eruptions that displace water by depositing large amounts of volcanic debris can generate a tsunami.

Tuff cone. A volcanic cone formed by a shallow explosive eruption in an area where surface water is located above the vent. Tuff cones have bedding angles of $20-25^{\circ}$ near the rim crests.

Vent. An opening in the earth's surface through which magma erupts or volcanic gases are emitted.

Vesicular. Characterized by or containing vesicles. Vesicles are small cavities in a glassy igneous rock, formed by the expansion of a bubble of gas or steam as a rock cools and hardens. 
H. OF THE

s-

a

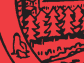

5 